\title{
How does the suspended sediment yield change in the North Caucasus during the Anthropocene?
}

\author{
Anatolii Tsyplenkov ${ }^{1}$, Valentin Golosov ${ }^{1}$, and Pelagiya Belyakova ${ }^{2}$ \\ ${ }^{1}$ Lomonosov Moscow State University \\ ${ }^{2}$ Russian Academy of Sciences
}

June 21, 2021

\begin{abstract}
Quantifying and understanding catchment sediment yields is crucial both from a scientific and environmental management perspective. To deepen the understanding of land use impacts and climate change on sediment load, we explore mechanisms of the suspended sediment yield formation in the Northern Caucasus during the Anthropocene. We examine how sediment flux of various river basins with different land-use/landcover and glacier cover changes during the 1925-2018 period. Our analysis is based on observed mean annual suspended sediment discharges (SSD, $\mathrm{kg} \cdot \mathrm{s}-1$ ) and annual fluxes (SSL, $\mathrm{t}^{*} \mathrm{yr}-1$ ) from 33 Roshydromet gauging stations (Russia). SSL series have been analyzed to detect statistically significant changes during the 1925-2018 period. The occurrence of abrupt change points in SSD was investigated using cumulative sum (CUSUM) charts. We found that SSL has decreased by $-1.81 \%$ per year on average at most gauges. However, the decline was not linear. Several transition years are expected in the region: increasing trends from the 1950s and decreasing trends from 1988-1994. Correlation analyses showed that variation in SSL trend values is mainly explained by gauging station altitude, differences in land use (i.e., the fraction of cropland), and catchment area. Nonetheless, more accurate quantifications of SSL trend values and more refined characterizations of the catchments regarding (historical) land use, soil types/lithology, weather conditions, and topography may reveal other tendencies.
\end{abstract}

\section{Introduction}

Quantifying and understanding catchment sediment yields $\left(S Y, \mathrm{t} \mathrm{km}^{-2} \mathrm{y}^{-1}\right.$; i.e., the amount of sediments exported from a river system per unit of time and catchment area) has been a central research theme for many decades. Over this time, it became increasingly clear that humans have a strong and rapidly growing impact on SY (Walling and Fang, 2003; Syvitski et al. , 2005; Montgomery, 2007; Borrelli et al. , 2017). Quantifying and understanding these impacts is not only a key research challenge in hydrology and fluvial geomorphology (Hoffmann et al. , 2010; Tarolli, 2016; Poesen, 2018) but also of great societal/economic relevance and necessary to fully understand anthropogenic impacts on carbon fluxes and the Earth System as a whole (e.g., Oost et al. , 2007; Galy et al. , 2015).

From earlier work, it became evident that human impacts on sediment fluxes are highly scale-dependent (Walling, 1988; Walling and Fang, 2003). Hillslopes and small catchments typically demonstrate a much stronger and faster response to land-use changes than larger river systems (Dearing et al. , 2006; Montgomery, 2007; Montanheret al. , 2018). This is also apparent at a global scale: estimates of impacts of human land cover changes on hillslope erosion rates (Oostet al. , 2007; Borrelli et al. , 2017) are about ten times larger than the corresponding impact on the sediment flux to the oceans (Syvitski et al., 2005). While the general mechanisms explaining this scale-dependency are known (e.g. Trimble, 1999), its characteristics and relation to other environmental factors remain poorly quantified and comprehended (Dearing et al. , 2006; Hoffmann et al. , 2010; Tarolli, 2016; Poesen, 2018). Nevertheless, understanding the sensitivity and scale dependency of river systems to human disturbances is crucial for effective catchment and land management strategies 
(Trimble, 1999; Vanmaercke et al. , 2011; de Vente et al. , 2013; Poesen, 2018) and strongly links to ongoing debates about the role of (historic) land use as the primary driver of soil erosion and land degradation in the Mediterranean and other regions (Cox et al. , 2010; García-Ruiz, 2010; Dusaret al. , 2011; Vanacker et al. , 2014). Detailed catchment sediment budget studies or lake sediment analyses can provide valuable insights into the history and degree of human impacts on $S Y$ (Trimble, 1999; Dearing et al. , 2006; Hoffmann et al. , 2010; Dusar et al. , 2011; Golosov et al. , 2021; Ivanovet al. , 2021).

However, the human factor is not the only one controlling the sediment flux - variations in SY are driven by a wide range of natural factors, including geomorphic, tectonic, climatic, and biotic factors (e.g. Syvitski and Milliman, 2007). For example, it was shown that interactions between lithology and seismicity could exert strong controls on erosion and catchment denudation rates via the effect of rock fracturation (Molnar et al. , 2007; Portenga and Bierman, 2011; Vanmaercke et al. , 2014b, 2017). While some recent works revealed no significant climatic impact on natural SY (Vanmaerckeet al. , 2014a), this factor will likely be more relevant at a temporal scale for mountain regions (Carretier et al. , 2013; Jeffery et al. , 2014).

To deepen the understanding of the impacts of land use and climate change on sediment load, we explore mechanisms of the suspended sediment yield formation in the Northern Caucasus during the Anthropocene (Waterset al. , 2014, 2016).

The collapse of the Soviet Union in 1991 has led to significant land reforms in Russia (Ioffe et al. , 2004; Golosov et al. , 2018), including the Caucasus region (Hartvigsen, 2014). Agricultural land previously owned by the State and used for large-scale farming was privatized in the early 1990s by distributing ownership rights to large state farms among former collective farm members (Hartvigsen, 2014). Overall, the economy's restructuring has led to agricultural land abandonment in the former Soviet Union (Lesiv et al. , 2018). Recent studies show that Northern Caucasus has cropland loss byca. 8\% in 2015 compared to 1987 (Buchner et al. , 2020). However, common for former Soviet Union forest recovery on abandoned agricultural fields (Griffiths et al. , 2014) has resulted in forest gain of 6\% in the Northern Caucasus (Buchner et al. , 2020).

The Northern Caucasus has experienced climate changes over the past decades, with summer temperature increased by $0.5-0.7^{\circ} \mathrm{C}$ over the past 30 years (Toropov et al. , 2019). The recent warming over the Caucasus Mountains has substantially impacted the glaciers, leading to losses at an average of $0.46 \%$ of the glacierized area per year (Tielidze and Wheate, 2018). However, the water cycle's associated intensification did not cause any significant change in the precipitation regime (Toropov et al. , 2019). Recent studies on the North Caucasus rivers (Rets et al. , 2020) show that June runoff increased by 1.1-9.1\% per decade for the last 70 years, while August's runoff from highly glacierized catchments has decreased by 1.0-6.3\% per decade. In contrast, the August runoff of non-glacierized catchments has increased by $1.5-11.5 \%$ per decade. With the growth of interest in environmental change over the Caucasus Mountains (Tielidze and Wheate, 2018; Toropov et al. , 2019; Rets et al. , 2020), it is crucial to consider the extent to which sediment flux is changing, as an important index of the functioning of the earth system mainly in response to landuse and climate changes (Walling and Fang, 2003).

Based on previous studies relating to sediment flux response to climate change (Walling and Fang, 2003; Li et al. , 2020; Zhang et al. , 2020), we hypothesized that in mountain and high-mountain catchments of the Northern Caucasus, the suspended sediment discharge values (SSD , $\left[\mathrm{kg} \mathrm{s}^{-1}\right]$ ) have been decreasing since the beginning of the Anthropocene in $c a$. 1945. To test this hypothesis, we analyzed catchment suspended sediment yields calculated using observed hydrological data. We explore how sediment flux of various river basins with different land-use/landcover and glacier cover changes over time. We mainly focused on small catchments $\left(\mathrm{A}<10^{3} \mathrm{~km}^{2}\right)$ as they are typically more sensitive to human impacts (Walling, 1983; Dearing and Jones, 2003; Vanmaercke et al. , 2015) and climatic change (Oswoodet al. , 1992; Moore et al. , 2009).

\section{Materials and Methods}

\subsection{Data}

This research used sediment transport data from 33 gauging stations of the Russian Federal Service for 
Hydrometeorology and Environmental Monitoring (Roshydromet) located in the Terek River basin in the Northern Caucasus (cf. Table 1 and Fig. 1 for location). This dataset covers a period from 1925 to 2018 (seeTable 1 for details). It consists of average annual suspended sediment discharges $\left(S S D, \mathrm{~kg}^{*} \mathrm{~s}^{-1}\right)$ and annual suspended sediment load $\left(S S L, \mathrm{t}^{*} \mathrm{yr}^{-1}\right)$. In this study we sometimes opt to an $S S D$ as a proxy of $S S L$.

We have split our database into three groups according to the gauging station altitude, i.e., low mountains $(<500 \mathrm{~m})$, middle mountains $(500-1000 \mathrm{~m})$, and high mountains $(>1000 \mathrm{~m})$. It should be noticed that bedload data is not available for rivers of the Terek River basin.

\#\#\# TABLE 1 \#\#\#

\#\#\# FIGURE 1 \#\#\#

According to Handbook for hydrological measurements at these gauging stations (РД 52.08.104-2002), suspended sediment data is collected using depth-integrated sediment samplers. The samples should be mainly collected once (at 8:00 AM) or twice a day (at 8:00 AM/PM), depending on the river and its flow regime. Then water samples are filtered using paper filters with a pore diameter of $2-3 \mu \mathrm{m}$. This is crucial, as, in sediment transport studies, membrane filters with a pore diameter of $0.45 \mu \mathrm{m}$ are more common (Kennedy et al. , 1974). Therefore, uncertainties related to this issue are discussed in an appropriate section.

Suspended sediment discharge in the upper Terek basin is characterized by a seasonal pattern typical for an Alpine environment (Fig. 2 ). During winter (November-March), sediment sources are limited because a significant fraction of the catchments is covered by snow, and precipitation occurs in solid form. Streamflow is mainly determined by baseflow (Rets et al. , 2018; Kireeva et al. , 2020), and SSD reaches the lowest values. In spring, $S S D$ increases when snowmelt-driven runoff mobilizes sediments along hillslopes and in channels. Simultaneously, snow cover decreases, and rainfall events over gradually increasing snow-free surfaces erode and transport sediment downstream, resulting in SSD peaks in June-July.

\#\#\# FIGURE 2 \#\#\#

Several Caucasian rivers are regulated with dams and diversions constructed and operated for hydropower production (seeSupplementary $\mathbf{1}$ ). Most of them are small run-of-river hydropower plants ( $<10$ megawatts $[\mathrm{MW}])$, but there are also run-of-river medium-sized ones (10-100 MW). Such diversion projects aim to channel a portion of the river through a canal or penstock to produce electrical energy. However, the role and importance of flow diversion for small hydroelectric power plants on suspended sediment transport are currently unclear. Indeed, this type of hydropower plant in steep mountain rivers has the lowest impact on sediment flow than other hydropower plant types (Kondolf, 1997). A recent study by Csiki and Rhoads (2010) shows that run-of-river dams have almost no impact on fine suspended sediment flux if the dam is fully submerged. Moreover, the transport of fine and coarse sediments should be unimpeded during high flow periods (Angelaki and Harbor, 1995; Csiki and Rhoads, 2010). We checked literature, photos, and satellite images for every of the $18^{\text {th }}$ hydropower plants. We assume that only 8 of them have altered the suspended sediment flux (see Supplementary 1 ). These are mostly run-of-river dams with in-channel reservoirs, e.g., Zaramagskaia, Kashkhatau, Gizeldonskaia, etc. The others either have a low-height dam $(<2 \mathrm{~m})$, which leads to minimal upstream sediment deposition (e.g., Kokadoiskaia, Fasnalskaia, Mukholskaia, etc.), or they are located on irrigation channels (e.g., Psykhurey, Akbashskaya) or lakes (e.g., Bekanskaya).

\subsection{Trend analysis}

Different statistical procedures can be used to detect a trend of $S S L$. In this study, we applied a parametric approach used in Rets et al. (2020) to compare $S S L$ trends with their findings on water discharge $(Q$, $\left.\mathrm{m}^{3} \cdot \mathrm{s}^{-1}\right)$ trends. Since this method is not presented clearly in the source paper, we explain it below. In this approach, the slope estimator is a coefficient $\beta$ from a linear model (estimated using Ordinary Least Squares (OLS)) fitted to predict $S S L$ with a year (yr ). It can be calculated as follows:

$\mathrm{SS} \mathrm{L}=\alpha+\beta y r,(1)$ 
$\overline{\mathrm{SSL}}=\frac{\sum_{i=1}^{n} \mathrm{SS} L_{i}}{n},(2)$

slope $e_{\mathrm{OLS}}=100 \frac{\beta}{\mathrm{SSL}},(3)$

Where: $\alpha$ is a model intercept; SŜL is a predicted suspended sediment load; $\operatorname{SS} L_{i}$ is suspended sediment load at year $i ; n$ is a total length of the observation period in years; $\overline{\text { SSL }}$ is a mean suspended sediment load for $n$ years. Thereforeslope $e_{\mathrm{OLS}}$ express the trend in percent per year.

\subsection{Landuse/landcover change assessment}

We used several regional studies for the quantitative assessment of changes in landuse and landcover. Thus, cropland and forest areas for 1987-2015 were calculated based on Buchner et al. (2020). While glacier areas for 1960-2014 were derived from Tielidze and Wheate's (2018) study. For several rivers (e.g., Ardon, Argun, Genaldon, and Sunzha), glacier areas were calculated manually from the GLIMS database (Raupet al. , 2007) since there was no requested information about them in Tielidze and Wheate paper. To estimate landuse and landcover change, we applied the same technique as above (Eq. (1-3)).

\subsection{Cumulative sum charts}

We used the cumulative sum (CUSUM) to demonstrate graphically long phases of the suspended sediment discharges. The CUSUM charts section with an ascending trend indicated a period in which the values were above the overall average. Similarly, the section with a descending trend showed a period in which the values were below the overall average.

This approach is relatively robust compared to other tests (Buishand, 1982) for a change-point that occurs toward the time series center (Kundzewicz and Robson, 2004). We used the techniques developed by Taylor (2000) that combine CUSUM charts and bootstrapping to compute 10000 iterations of the CUSUM chart. This approach is widely used in hydroclimatic studies (e.g., Mavromatis and Stathis, 2011; Fischeret al. , 2012; Salerno et al. , 2012; Liuzzo et al. , 2017). We did all computations in R using the ChangePointTaylor package (Marks, 2020).

For each change, this change-point analysis approach estimates (1) a confidence level, indicating the likelihood (with a confidence level of [?] 80\%) of that change and (2) a confidence interval (with a confidence level of [?]95\%), indicating the time of the specific change occurred. This method also controls the change-wise error rate and is robust to outliers. More regarding this approach can be found in Taylor (2000).

We also applied a Pettitt (1979) test for single-point detection, another widely used technique (Zhang et al. , 2008; Gao et al. , 2011; Rets et al. , 2020). This rank-based nonparametric technique can be more robust as it is distribution-free and insensitive to outliers and data skewness. It tests the time series for a single change in the mean with an exact unknown time of transition.

Multiple regression models were used to impute missing values in mean annual suspended sediment discharges. Models explained $68 \%$ of the variance in $S S D$ on average. They included as predictors an annual sum of liquid precipitation $(P, \mathrm{~mm})$, number of wet days in a year ( $n_{-}$rain , days), simple precipitation intensity index $(S D I I)$, mean annual air temperature (Tav, $\operatorname{deg} C$ ), number of warm days (with the average daily air temperature above $5 \mathrm{deg} C$ ) in a year (Tsum, days). These parameters were estimated based on meteorological observations at seven meteorological stations: Kluhorskij pereval, Gudermes, Vladikavkaz, Kazbek mountain, Nalchik, Shadzhatmaz, and Oni (see Fig. 1 for their location). Model description and performance metrics are presented in Supplementary 2.

Daily summaries of air temperature and precipitation were provided by the NOAA Global Historical Climate Network from their website https://www.ncdc.noaa.gov/cdo-web/. We used a +2.0 degC rain-snow temperature threshold (i.e., the $50 \%$ rain-snow air temperature threshold estimated by Jennings et al. (2018)) to estimate $P$ and $S D I I$.

\subsection{Double Mass Curve}


The double mass curve is a simple, visual, and practical method, and it is widely used to study the consistency and long-term trend test of hydrometeorological data (Wei and Zhang, 2010; Gao et al. , 2011; Aryal and Zhu, 2020). The double-mass curve theory is based on the fact that a plot of the two cumulative quantities during the same period exhibits a straight line so long as the proportionality between the two remains unchanged. The slope of the line represents the proportionality. This method can smooth a time series and suppress random elements in the series, thus showing the time series's main trends (Gao et al. , 2010).

In this study, double-mass curves of summer precipitation vs. suspended sediment discharge are plotted for the two different periods to estimate changes in regression slope (proportionality) to quantify the impact of rainfall on $S S D$ before and after transition years. We used TerraClimate (Abatzoglou et al. , 2018) precipitation sums for June-August that were spatially averaged over every river basin.

\subsection{Uncertainty assessment}

Uncertainties on suspended sediment load values were simulated by considering the most critical sources of measuring errors. More specifically, other potential $S S L$ values were simulated using the following equation, modified from Vanmaercke et al. (2015):

$\mathrm{SS} L_{\mathrm{sim}}=S S L \times U_{\mathrm{ME}}+S S L \times U_{\mathrm{FF}},(4)$

where $S S L_{\text {sim }}$ is another potentially true value of $S S L$ after considering the various sources of uncertainty. $U_{M E}$ reflects the uncertainties associated with measuring errors, $U_{F F}$ represents the uncertainty associated with the unmeasured finer fraction. In the original equation from Vanmaercke et al. (2015), two more potential sources of uncertainty are discussed: low sampling frequency and length of measuring period. The latter is not applicable for our data as we are dealing with annual values. We also assumed that sampling frequency might not be a source of uncertainty in our case, as with daily sampling intervals, both bias and imprecision tend to zero (Moatar et al. , 2006).

$U_{M E}$ reflects the integrated effect of errors on individual runoff discharge measurements, suspended sediment concentration measurements, and uncertainties due to intra-daily variation in runoff and sediment concentrations not captured by the measurements. Previous studies reported that these errors are commonly 20-30\% (Steegen and Govers, 2001; Harmel et al. , 2006; Vanmaercke et al. , 2015). We, therefore, expected that $30 \%$ provides a realistic and relatively conservative estimate of the uncertainty on SY-values associated with measuring errors. Hence, $U_{M E}$ was simulated as a random number from a normal distribution with a mean of 1 and a standard deviation of 0.30 .

However, $S S L$ values derived from measurements at gauging stations in Russia are subject to additional uncertainties associated with filter type and may underestimate the actual suspended sediment load (Chalovet al. , 2019). At Russian gauging stations, suspended sediment concentration is measured by the gravimetric method using paper filters with pore sizes ranging from 2 to $3 \mu \mathrm{m}$ (so-called «blue tape», de-ashed filters, «TY 6-09-1678-86» specification) according to Handbook. One may argue that our results are incomparable with other findings (Kasperet al. , 2018). However, from previous studies (Bogen, 1989; Williams and Rosgen, 1989), we know that the $>5 \mu \mathrm{m}$ fraction constitutes most of the suspended load in the glacierized and mountainous catchments. Therefore, we assume that our sediment data may be a good indicator of the total sediment output from the study catchments.

To estimate how pore size can impact total suspended sediment concentration, we performed a brief exploratory data analysis of particle size distribution from Williams and Rosgen (1989). We selected only nine mountainous rivers flowing in similar environmental conditions as those presented in this study from their dataset. We found that out of 216 samples mean percent by weight finer than $4 \mu \mathrm{m}$ is $24.7 \%$, with a corresponding standard deviation of $9.5 \%$. The proportion of finer fraction can vary from $8 \%$ to $43 \%$ (i.e., the $2.5 \%$ and $97.5 \%$ quantile) depending on the season and river. Hence, $U_{F F}$ was simulated as a random number from a normal distribution with a mean of 0.247 and a standard deviation equal to 0.095 . Evidently, $U_{F F}$ values were restricted to values between 0.08 and 0.43 .

Equation 4 was used to simulate respectively 1000 alternative SSLfor every year and every gauging station. 
From these values, we calculated $95 \%$ confidence intervals on every $S S L$ value (i.e., the difference between the $97.5 \%$ and $2.5 \%$ quantile of the 1000 simulated values).

Buchner et al. (2020) reported that the overall accuracy of the cropland change map is $75.7 \%$, of the forest change map is $90.2 \%$. Therefore, uncertainties of the landcover change associated with measuring errors were simulated as a random number from a normal distribution with a mean of 1 and a standard deviation of 0.24 for cropland and 0.1 for a forest.

Various data sources (global satellite imagery, aerial photos, and topographic maps) were used to create the Greater Caucasus glacier inventory (Tielidze and Wheate, 2018), so the glacier area error varies through time and between methods from $4.4 \%$ to $7.9 \%$. We assumed that an $8 \%$ error provides a realistic estimate of the glacier area uncertainty. In the result, the uncertainty was simulated as a random number from a normal distribution with a mean of 1 and a standard deviation of 0.08 .

\section{Results}

\subsection{Trend analysis}

The results of the suspended sediment load trend analysis are summarized in Table 2. Annual SSL decreased at most measurement stations, while increasing trends occasionally occurred, affecting only individual cases. A decrease in $-0.117 \%--21.4 \%$ per year is registered at 28 of 33 gauging stations. The average measured recession is $-1.81 \%$ per year (stand. dev. 3.89). Positive trends are observed in all altitude zones. The mean annual increase in suspended sediment load is $2.95 \%$ (stand. dev. 5.68). It varies from 0.259 to $13.1 \%$ (seeTable 2 ).

To make our results comparable to the findings of Buchner et al. (2020), we calculated trends for the same period as their forest and cropland change (1987-2015). At all gauges combined, we observed a steeper decline in the contemporary period rather than for the whole available measuring history. The Fiagdon river is the only exception with a shift in the trend direction at Tagardon station (Fia-Ta). The average measured recession in the 1987-2015 period is $-11 \%$ per year (stand. dev. 9.6).

\#\#\# TABLE 2 \#\#\#

\#\#\# FIGURE 3 \#\#\#

\subsection{Land use and land cover change}

Changes in cropland, forest, and glacier areas were analyzed for every catchment (Table 2 ). It was found that both glacier and cropland exhibited negative trends in most cases during the last 30 years. Glacier trends had magnitudes that varied between $-0.27 \%$ and $-1.79 \%$ per year, while the range of magnitude of cropland trends was $-0.07 \%$ to $-2.53 \%$. The river basin of Gen-Tm is the only one with a positive cropland trend. Cropland area is increased from 1987 to 2015 by $0.48 \%$ per year.

\subsection{Cumulative sum charts}

Further analysis of suspended sediment discharge was carried out for eight gauging stations (Ard-Ta, Bel-Ko, Che-Ba, Cheg-Nc, Kam-Ol, Mal-Ka, Sun-Br, Uru-Kh, see Fig.1 for location) with the most extended series of observation and not altered by HPP. Table 3 summarizes the results for each analyzed gauging station. The CUSUM charts are reported in Fig. 4 ; the change points are indicated with grey (Taylor, 2000) and red (Pettitt, 1979) lines.

The CUSUM chart analysis demonstrates similarities between the seven river basins except for Uru-Kh. Indeed, all series showed a change point approximately within the same range of years, increasing trends from the 1950s and decreasing trends from 1988-1994.

It can be noticed that mean annual $S S D$ values tend to decline at the beginning of the observation period at Ard-Ta, Cheg-Nc, Sun-Br, and Bel-Ko (from 1945 to 1950s). For example, the analysis highlighted that the $S S D$ at Sun-Br underwent a significant change in 1958 (confidence interval 1957-1977) at a confidence 
level of $82 \%$. After that, an increasing trend occurred at Ard-Ta, Cheg-Nc, Sun-Br, and Bel-Ko stations. A similar trend fluctuation was observed at the Che-Ba and Mal-Ka stations, where the average annual SSD has been subject to a moderate increase up to the $c a .1990$.

According to Taylor's (2000) change point method, a decreasing trend in annual average SSD occurred during time window 1988-1994 at almost every gauging station with a 99.9-100\% confidence level (see CI intervals in Table 3 ). In addition, at several stations (i.e., Ard-Ta, Cheg-Nc, Sun-Br, Mal-Ka), the change point location in the 1990s was proven with both methods.

A slightly different pattern is observed on the Kam-Ol and Uru-Kh stations. From the 1960s to the 1980s, the average annual $S S D$ has been subject to a sharp decrease followed by an increase up to 1994 (Kam-Ol) and 2005 (Uru-Kh). Thus, these trends resulted in a change point at a 99.9\% confidence level for the KamOl series. However, Uru-Kh's change point in 2005 was proven neither by Taylor (2000) nor Pettitt (1979) techniques. After 1990 (or 2005), a moderate decrease occurred up to 2018.

\#\#\# FIIGURE 4 \#\#\#

\#\#\# TABLE 3 \#\#\#

\subsection{Double Mass Curves}

According to CUSUM analysis, there is evidence that mean annual SSD values significantly decline after 1988-1994 depending on the gauging station. Transition years for every gauging station identified by Taylor's method are summarized in Table 4 . To further quantify the sediment discharge changes before and after the transition years, double mass curves, along with the linear regression lines, were plotted in Figure $\mathbf{5}$. There are precise breakpoints between the two regression lines, suggesting that the selected transition years are correct and meaningful. The regression lines' slopes were 1.5-4.5 times lower after the breakpoints or transition years (i.e., at higher cumulative precipitation values) than before (see equations inFigure 5 ).

To estimate the relative reduction of total sediment discharge for the period after the transition years, linear models describing the cumulative $S S D$ before the transition years were used to further extrapolate the cumulative sediment up until 2018 (dashed line inFigure 5 ). Compared with the extrapolated cumulative sediment discharge $\left(S S D_{C}\right)$, observed cumulative sediment discharge $\left(S S D_{O}\right)$ reduced by $11-43 \%$ in various basins (Table 4 ).

\section{\#\#\# TABLE 4 \#\#\#}

\#\#\# FIGURE 5 \#\#\#

We further calculated suspended sediment discharge for the period after the transition years using the regression equations established from the double mass curve of precipitation-sediment before the transition years (cf. Figure 5 ). The difference between observed valuesSS $D_{O}$ before the transition year and estimated $\mathrm{SS} D_{C}$ after the transition year is due to precipitation change. However, the difference between the estimated mean values $\mathrm{SS} D_{C}$ and observed values $\mathrm{SS} D_{O}$ in the same period is the result of other factors (e.g., human activities, glacier shrinkage, sediment source depletion, etc.). The results are shown inTable 5 .

The impact of additional factors was dominant in all cases for the sediment discharge reduction. Their average contribution rate is $87.8 \%$ which is more robust than the average precipitation rate $(12.2 \%)$. Indeed, the impact of precipitation varies from basin to basin and can explain up to $21 \%$ of sediment discharge reduction (e.g., Fia-Ta). Contrariwise, the Kam-Ol basin precipitation events almost did not alter the sediment discharge $(5 \%)$. Therefore, there is evidence that precipitation played a minor role in the suspended sediment discharge reduction in the upper Terek basin during the last decades.

\#\#\# TABLE 5 \#\#\#

\section{Discussion}

\subsection{Trend}


At all gauges combined by altitude groups, median values of SSLtrends increase with the height (Figure 6 ). This is a piece of evidence that higher gauging stations are less exposed to a considerable reduction in suspended sediment load. On the other hand, there is a lack of suspended sediment measurements in the 2000s and 2010s in this database. Our last findings (Tsyplenkov et al. , 2021) from the Djankuat river station near Elbrus mountain (ca. $2700 \mathrm{~m}$ a.m.s.l.) suggested a decline in 20-37\% in suspended sediment load during the 2015-2019 period. Therefore, a tendency of declining absolute trend values with the altitude should be discussed with caution.

We found that the mean annual SSD change pattern has considerably altered after 1988-1994 depending on the gauging station from the performed CUSUM analysis. Therefore, although it is hard to determine an exact transition year for the whole Caucasus region, we can assume with the high confidence level (cf.

Table 3 ) that it was in the 1988-1994 period. This finding is in line with other studies on the water runoff for the Caucasus region (Rets et al. , 2018, 2020), whereas it was suggested 1986 as a transition year.

To a significant extent, calculated $S S L$ trends correspond to water discharge trends (Rets et al. , 2020) and suspended sediment load changes (Gusarov et al. , 2021) calculated previously for the Greater Caucasus (Table 6 ). Therefore, we performed a correlation analysis using a nonparametric Spearman correlation coefficient to compare our findings with previous studies. As a result, we observed an insignificant negative correlation between the trend $S S L$ values from our research and a change in suspended sediment load from Gusarov et al. (2021) (Spearman $\mathrm{r}=-0.8, \mathrm{p}=0.1$ ).

Also, a significant negative correlation between change in mean July's water discharge and $S S L$ trends was observed (Spearman $\mathrm{r}=-0.7, \mathrm{p}=0.06$ ). The correlation with June's (Spearman $\mathrm{r}=-0.45, \mathrm{p}=0.26$ ) and August's (Spearman $\mathrm{r}=-0.42, \mathrm{p}=0.3$ ) mean monthly discharges were lower. Since the significance level is weak, this result should be interpreted with caution. Nevertheless, it is likely that monthly runoff in July to some extent more reflects the climatic sensitivity of catchments in terms of sediment export than monthly runoff in June and August. However, a comparison of peak water discharge trends with SSL suggests that not always a drop in $S S L$ trend results from water discharge reduction. For example, the observed positive trend in peak annual water discharge at Kam-Ol $(+0.27 \%$ per year) corresponds to a decline in annual $S S L$ at $-1 \%$ per year.

\#\#\# FIGURE 6 \#\#\#

\#\#\# TABLE 6 \#\#\#

\#\#\# FIGURE 7 \#\#\#

\#\#\# FIGURE 8 \#\#\#

We did observe a negative correlation between the $S S L$ trend values and the catchment area (Spearman $\mathrm{r}$ $=-0.25, \mathrm{p}=0.17)$. However, further exploration of this scale dependency indicated significant differences, depending on the altitude zone. Hence, when only the low to a middle mountain (500-1000 m) catchments were considered, a highly significant positive correlation between $S S L$ trend and catchment area was observed (Spearman $\mathrm{r}=0.86, \mathrm{p}<0.0001)$. The catchment area explains $71 \%$ of the variation in $S S L$ trend values of low to middle mountain $(500-1000 \mathrm{~m})$ catchments (Fig. 7a ). Since the observed total correlation is relatively weak and cannot be straightforwardly explained by a transparent mechanism, this result should be interpreted cautiously.

Nevertheless, likely, suspended sediment load trends are indeed scale-dependent in Northern Caucasus. The gauging station altitude most likely explains this scale-dependency since smaller catchments tend to locate higher in the mountains and be more glacierized and less cultivated (Fig. 7b-c ).

Similar results were obtained for 1000 generated sets of SSLtrend values (Section 2.6), confirming that these correlations are not attributable to calculating or measuring errors (Fig. 8 ). We found that SSL trend values of a low mountain $(<500 \mathrm{~m})$ gauging stations are significantly positively correlated to altitude and glacier fraction and significantly negatively to cropland area. However, in another altitude zone (500-1000 
$\mathrm{m})$, the catchment area became the most valuable positive factor, while the correlation with altitude and glacier should be considered insignificant. A correlation with controlling factors in high mountain catchments was insignificant.

\subsection{Human impact on $S Y$}

Our results indicate that the cropland fraction in a catchment is significantly negatively correlated with the $S S L$ trend (Spearman $\mathrm{r}=-0.64, \mathrm{p}<0.001$ ). This is likely indicating that the $S S L$ decline in highly cultivated basins tends to be sharper than the corresponding sediment load under pristine conditions. Therefore, this study opts for a cropland fraction as a proxy of landuse impact on suspended sediment load. One may argue that not only arable land but also other anthropogenic land use types (e.g., pasture) can affect the suspended sediment yield. However, previous studies (Vanmaercke et al. , 2015) suggest that land use impacts on suspended sediment load are mainly caused by agriculture (i.e., arable land and permanent crops).

Nevertheless, the influence of anthropogenic activity on the sediment flux of the Caucasus rivers can be multidirectional in the coming decades. On the one hand, the construction of new ski pistes contributes to an increase in sediment export from the catchment area. This is also facilitated by the construction of hotel complexes and other infrastructure in resort areas. On the other hand, a decline of pressure on mountain pastures due to a livestock amount decrease is typical for this part of the Greater Caucasus. For example, land abandonment is also common for the mid-mountainous and low-mountainous zones in many regions of the Mediterranean (Rodrigo-Comino et al. , 2018). As a rule, these were arable lands, and therefore, in the first years after the abandonment of lands, an increase in sediment runoff occurred. However, as the slopes were overgrown, the sediment runoff sharply decreased (Lizaga et al. , 2018).

There is some evidence that cropland and glacier change have minimal impact on the rivers regulated with HPP. On the other hand, they possibly have influenced suspended sediment fluxes of other rivers. We can suppose that most of the $S S D$ reduction in the Mal-Ka, Kam-Ol, Cheg-Nc was related to cropland changes between 1987 and 2015, while the precipitation regime changes have a weaker effect (see Table 5 ). Cropland area was much more stable in the Ard-Ta, Bel-Ko, Che-Ba, and Uru-Kh basins, suggesting the leading role of deglaciation in $S S D$ reduction (precipitation change explains up to $22 \%$ of $S S D$ reduction, cf. Table 5 ) in combination with other climatic factors. In the Sunzha basin (Sun-Br and Sun-Gr), both cropland and glacier were much more variable, and the amount of cultivated cropland dropped significantly from 2010 to 2015. While precipitation changes explain only $7 \%$ of the $S S D$ reduction, the other $93 \%$ are mostly connected to the land reforms (cropland decrease) and glacier shrinkage.

At the same time, in the foothill zone, after a slight decline in agriculture in the 1990s, there is a gradual expansion of the area of cultivated land. In particular, the number of orchards is increasing and the area under cultivation of raw crops. In addition, the creation of a network of small ponds and reservoirs in the foothill zone contributes to the redeposition of a part of the sediment coming from the slopes into permanent streams. The influence of dams on the sediment runoff of mountain rivers is typical for many mountain areas. Most of the rivers in the Alps are regulated by a system of dams, which significantly affects the trends in the change in sediment runoff and does not allow the influence of climatic changes on them to be revealed with the necessary detail (Costa et al. , 2018). Also, it can be hypothesized that suspended sediment yield flux will continue to decline as the number of hydropower plants increases worldwide and in North Caucasus in particular (Fel'dman, 1985; Zarfl et al. , 2015).

\subsection{Climate influence}

The influence of climate change on the formation of sediment load in the rivers of the North Caucasus is quite complex, which is due to differences in microclimatic conditions both in individual altitudinal zones and even between individual river basins. At the same time, the limited number of meteorological stations does not allow assessing the specificity of the influence of microclimatic characteristics on individual river basins (Toropov et al. , 2019). In this regard, it is possible to estimate most reliably the contribution of changes in mountain glaciation to the suspended sediment flux. Paleoreconstruction and direct observations 
demonstrated that the retreat of glaciers in the Caucasus continues throughout the middle 19-20th century with a slight slowdown in the period 1980-1990s and the sharp increase during the last two decades (Solomina et al. , 2016; Tielidze and Wheate, 2018; Verhaegen et al. , 2020). That is, it does not correlate with global warming in the last quarter of the 20th century. With a glacier area reduction, denudation processes are activated in the proglacial zone, which is reflected, among other things, in an increase in the frequency of debris flows. By the first decades of the 21st century, the area of glaciation in the Caucasus decreased the most sharply (Shahgedanova et al. , 2007). The frequency of debris flows has also decreased due to a reduction in the glacial component of water and sediment fluxes associated with a diminishing in the glacier area (Retset al. , 2020).

Nonetheless, also scale dependencies in sediment sources can play a role. For example, hillslope erosion processes (landslides, rockfalls) are often considerable sediment sources in small mountainous catchments and highly sensitive to climate change. Apart from debris flow, the frequency of rockfalls and rock avalanches is reported to increase in the $21^{\text {st }}$ century in the Caucasus (Dokukin et al. , 2020) and worldwide (e.g., Valderrama Murillo and Vilca, 2012; Byers et al. , 2019).

Overall, our findings are in line with the studies mentioned above. In addition, we found that the share of the glacierized area has a strong positive impact on $S S L$ trends (Spearman $\mathrm{r}=0.73, \mathrm{p}<0.0001$ ). This indicates that $S S L$ of more glacierized catchments is likely to decrease slower (Fig. $7 \mathbf{b}$ ) or even increase in some cases (cf. Table 2 ). Surprisingly, the impact of glacier cover is significant only for gauging stations located in lowlands (Fig. 8a ).

An indicator of the influence of local microclimatic conditions on the formation of water and sediment runoff in the proglacial zone is the different rate of glacier retreat, depending on differences in exposure, topography, and other landscape characteristics (Tielidze and Wheate, 2018). However, only the availability of water discharge measurements in combination with meteorological observations in the proglacial zone makes it possible to quantitatively assess the contribution of various microclimatic factors to the formation of river sediment flux. The opposite situation is observed on the Tibet plateau, where an increase in air temperatures provoked a sharp increase in the flow of water and sediment fluxes (Li et al. , 2020). This is due to the higher altitude of this region, which led to a time lag in the effect of global warming on the temperature regime.

\subsection{Uncertainties}

Among the uncertainty sources discussed in the corresponding section (section 2.6), we suppose that uncertainty in trend results is mainly attributed to data limitations. As suggested by previous studies (e.g., Onyutha, 2016), the uncertainty in the trend reduces as the series record length increases. These difficulties may be to some extent be solved by considering extended suspended sediment time series. However, it can be impossible for gauging stations in the Terek basin as many closed or stopped to measure suspended sediment yield. Likewise, future research may still benefit from considering a larger number of catchments from neighboring regions of the Greater Caucasus (e.g., Georgia, Armenia, Azerbaijan).

Even though we used data from 33 catchments (Fig. 1 ), which is significantly more than many other contemporary studies in that region (Gusarov et al. , 2021), this number may still be too small to identify the impact of all relevant factors. However, especially considering more high-altitude gauging stations (higher than $1000 \mathrm{~m}$ ) in the analyses could help since that altitude group is less populated with prolonged timeseries.

Furthermore, apart from potential cropland, no other factors could be identified that significantly correlated with the $S S L$ trend in high-mountain gauging stations (Fig. 8c ). In other words, our analyses provide no evidence that $S S L$ trend values for high mountain catchments (with a gauging station altitude higher than $1000 \mathrm{~m}$ ) depend on landuse/landcover or spatial scale. However, it should be emphasized that this does not necessarily imply that these factors cannot influence the $S S L$ change. The lack of significant correlations between $S S L$ trend values and the considered variables may also be attributed to the inherent limitations of our approach and a small number of gauging stations in this altitude group subset. 


\section{Conclusion}

For the Northern Caucasus region, where increased suspended sediment concentration is one of the environmental concerns, regional-scale studies on the temporal variability of sediment flux are lacking. This study explored temporal trends of suspended sediment load in the Terek River basin during 1925-2018 using observed suspended sediment discharge at 33 gauging stations. Our results provide one of the first robust assessments of the $S S L$ change and clearly indicate its decreasing trend over the last decades. In general, the suspended sediment flux over the last hundred years changes relatively synchronously for most rivers in the Terek basin, draining the Northern mega-slope of the Greater Caucasus. This indicates a vital role of natural factors since the influence of anthropogenic factors differs significantly for different river basins.

The CUSUM charts analysis revealed a change point roughly within the same range of years at various gauging stations. As a result, several transition years are expected in the Northern Caucasus: increasing trends from the 1950s and decreasing trends from 1988-1994. The latter is most likely due to a decrease in glacier areas and a decrease in the area of arable land. It is critical for catchments with a high cropland fraction located in the foothill belt $(<500 \mathrm{~m})$. At the same time, an absence of a pronounced trend or even an insignificant increase of suspended sediment flux was established for some river basins.

Our results were less clear for high-altitude catchments. Future research based on a more significant number and range of gauging stations located higher than $1000 \mathrm{~m}$ is required. Nonetheless, there are several reasons to expect that high-altitude gauging stations are less exposed to a considerable reduction in suspended sediment load (cf. Figure 6 ).

We found that summer precipitation controls up to $22 \%$ of mean annual suspended sediment discharge for the upper Terek basin rivers. Additionally, the reduction of croplands and glaciers has impacted the suspended sediment load. While it is impossible to measure their effect on the sediment yield quantitatively in this research, we suggest a qualitative assessment of their impact. The observed SSD changes in Malka, Kambileevka, Cheget, Ardon, and Sunzha are most likely connected to the collapse of the Soviet Union in 1991 and the subsequent land reforms and armed conflicts during the 1990s.

\section{Conflict of Interest Statement}

The authors declare that they have no known competing financial interests or personal relationships that could have appeared to influence the work reported in this paper.

\section{Data availability}

Reproducible $\mathrm{R}$ code and data are available at the GitHub repository (https://github.com/atsyplenkov/sediment-caucasus-anthropocene). Contact Anatoly Tsyplenkov (atsyplenkov@gmail.com) for more information.

\section{Acknowledgements}

The authors acknowledge the core team of the $\mathrm{R}$ statistical software for providing suite of functionalities. This work was conducted with support from the ongoing Russian Science Foundation project No. 19-1700181: "Quantitative assessment of the slope sediment flux and its changes in the Holocene for the Caucasus mountain rivers." This study contributes to the State Task no. 0148- 2019-0005, Institute of Geography RAS.

\section{References}

Abatzoglou JT, Dobrowski SZ, Parks SA, Hegewisch KC. 2018. TerraClimate, a high-resolution global dataset of monthly climate and climatic water balance from 1958-2015. Scientific Data 5 (1): 170191 DOI: 10.1038/sdata.2017.191

Angelaki V, Harbor JM. 1995. Impacts of Flow Diversion for Small Hydroelectric Power Plants on Sediment Transport, Northwest Washington.Physical Geography 16 (5): 432-443 DOI: 10.1080/02723646.1995.10642564 
Aryal Y, Zhu J. 2020. Effect of watershed disturbance on seasonal hydrological drought: An improved double mass curve (IDMC) technique.Journal of Hydrology 585 : 124746 DOI: 10.1016/j.jhydrol.2020.124746

Bogen J. 1989. Glacial Sediment Production and Development of Hydro-Electric Power in Glacierized Areas. Annals of Glaciology13 : 6-11 DOI: 10.3189/S0260305500007539

Borrelli P, Robinson DA, Fleischer LR, Lugato E, Ballabio C, Alewell C, Meusburger K, Modugno S, Schütt B, Ferro V, et al. 2017. An assessment of the global impact of 21st century land use change on soil erosion. Nature Communications 8 : 2013 DOI: 10.1038/s41467-017-02142-7

Buchner J, Yin H, Frantz D, Kuemmerle T, Askerov E, Bakuradze T, Bleyhl B, Elizbarashvili N, Komarova A, Lewińska KE, et al. 2020. Land-cover change in the Caucasus Mountains since 1987 based on the topographic correction of multi-temporal Landsat composites. Remote Sensing of Environment 248 : 111967 DOI: $10.1016 /$ j.rse.2020.111967

Buishand TA. 1982. Some methods for testing the homogeneity of rainfall records. Journal of Hydrology $\mathbf{5 8}$ (1): 11-27 DOI: 10.1016/0022-1694(82)90066-X

Byers AC, Rounce DR, Shugar DH, Lala JM, Byers EA, Regmi D. 2019. A rockfall-induced glacial lake outburst flood, Upper Barun Valley, Nepal.Landslides 16 (3): 533-549 DOI: 10.1007/s10346-018-1079-9

Carretier S, Regard V, Vassallo R, Aguilar G, Martinod J, Riquelme R, Pepin E, Charrier R, Hérail G, Farías M, et al. 2013. Slope and climate variability control of erosion in the Andes of central Chile.Geology 41 (2): 195-198 DOI: 10.1130/G33735.1

Chalov S, Terskii P, Efimova L, Terskaya A, Efimov V, Danilovich I, Koval M. 2019. Problems of hydrological monitoring in transboundary rivers of Eastern Europe (on the example of the Western Dvina).Engineering survey 13 (1): 32-45 DOI: 10.25296/1997-8650-2019-13-1-32-44

Costa A, Anghileri D, Molnar P. 2018. Hydroclimatic control on suspended sediment dynamics of a regulated Alpine catchment: a conceptual approach. Hydrology and Earth System Sciences 22 (6): 3421-3434 DOI: https://doi.org/10.5194/hess-22-3421-2018

Cox R, Zentner DB, Rakotondrazafy AFM, Rasoazanamparany CF. 2010. Shakedown in Madagascar: Occurrence of lavakas (erosional gullies) associated with seismic activity. Geology 38 (2): 179-182 DOI: 10.1130/G30670.1

Csiki S, Rhoads BL. 2010. Hydraulic and geomorphological effects of run-of-river dams. Progress in Physical Geography: Earth and Environment 34 (6): 755-780 DOI: 10.1177/0309133310369435

Dearing JA, Jones RT. 2003. Coupling temporal and spatial dimensions of global sediment flux through lake and marine sediment records. Global and Planetary Change 39 (1): 147-168 DOI: 10.1016/S0921$8181(03) 00022-5$

Dearing JA, Battarbee RW, Dikau R, Larocque I, Oldfield F. 2006. Human-environment interactions: learning from the past. Regional Environmental Change 6 (1): 1-16 DOI: 10.1007/s10113-005-0011-8

Dokukin M, Bekkiev M, Kalov R, Chernomorets S, Savernyuk E. 2020. Activation of rock avalanches in the Central Caucasus and their impact on the dynamics of glaciers and debris flows. Ice and Snow 60 (3): 361-378 DOI: $10.31857 /$ S2076673420030045

Dusar B, Verstraeten G, Notebaert B, Bakker J. 2011. Holocene environmental change and its impact on sediment dynamics in the Eastern Mediterranean. Earth-Science Reviews 108 (3): 137-157 DOI: 10.1016/j.earscirev.2011.06.006

Fel'dman BN. 1985. Hydropower engineering of the Northern Caucasus. Hydrotechnical Construction 19 (3): 124-129 DOI: 10.1007/BF01429086 
Fischer T, Gemmer M, Liu L, Su B. 2012. Change-points in climate extremes in the Zhujiang River Basin, South China, 1961-2007.Climatic Change 110 (3): 783-799 DOI: 10.1007/s10584-011-0123-8

Galy V, Peucker-Ehrenbrink B, Eglinton T. 2015. Global carbon export from the terrestrial biosphere controlled by erosion. Nature521 (7551): 204-207 DOI: 10.1038/nature14400

Gao P, Mu X-M, Wang F, Li R. 2011. Changes in streamflow and sediment discharge and the response to human activities in the middle reaches of the Yellow River. Hydrology and Earth System Sciences 15(1): 1-10 DOI: https://doi.org/10.5194/hess-15-1-2011

Gao P, Zhang X, Mu X, Wang F, Li R, Zhang X. 2010. Trend and change-point analyses of streamflow and sediment discharge in the Yellow River during 1950-2005. Hydrological Sciences Journal55 (2): 275-285 DOI: $10.1080 / 02626660903546191$

García-Ruiz JM. 2010. The effects of land uses on soil erosion in Spain: A review. CATENA 81 (1): 1-11 DOI: 10.1016/j.catena.2010.01.001

Golosov V, Yermolaev O, Litvin L, Chizhikova N, Kiryukhina Z, Safina G. 2018. Influence of climate and land use changes on recent trends of soil erosion rates within the Russian Plain. Land Degradation 85 Development 29 (8): 2658-2667 DOI: 10.1002/ldr.3061

Golosov VN, Ivanov MM, Tsyplenkov AS, Ivanov MA, Konoplev AV, Wakiyama Y, Konstantinov EA, Ivanova NN. 2021. Erosion as a Factor of Transformation of Soil Radioactive Contamination in the Basin of the Shchekino Reservoir (Tula Region). Eurasian Soil Science54 (2): 291-303 DOI: 10.1134/S106422932102006X

Griffiths P, Kuemmerle T, Baumann M, Radeloff VC, Abrudan IV, Lieskovsky J, Munteanu C, Ostapowicz K, Hostert P. 2014. Forest disturbances, forest recovery, and changes in forest types across the Carpathian ecoregion from 1985 to 2010 based on Landsat image composites.Remote Sensing of Environment 151 : 72-88 DOI: $10.1016 /$ j.rse.2013.04.022

Gusarov AV, Sharifullin AG, Komissarov MA. 2021. Contemporary Long-Term Trends in Water Discharge, Suspended Sediment Load, and Erosion Intensity in River Basins of the North Caucasus Region, SW Russia.Hydrology 8 (1): 28 DOI: 10.3390/hydrology 8010028

Harmel D, Cooper J, Slade M, Haney R, Arnold G. 2006. Cumulative uncertainty in measured streamflow and water quality data for small watersheds. Transactions of the ASABE 49 (3): 689-701 DOI: $10.13031 / 2013.20488$

Hartvigsen M. 2014. Land reform and land fragmentation in Central and Eastern Europe. Land Use Policy 36 : 330-341 DOI: 10.1016/j.landusepol.2013.08.016

Helena B, Pardo R, Vega M, Barrado E, Fernandez JM, Fernandez L. 2000. Temporal evolution of groundwater composition in an alluvial aquifer (Pisuerga River, Spain) by principal component analysis. Water Research 34 (3): 807-816 DOI: 10.1016/S0043-1354(99)00225-0

Hoffmann T, Thorndycraft VR, Brown AG, Coulthard TJ, Damnati B, Kale VS, Middelkoop H, Notebaert B, Walling DE. 2010. Human impact on fluvial regimes and sediment flux during the Holocene: Review and future research agenda. Global and Planetary Change 72 (3): 87-98 DOI: 10.1016/j.gloplacha.2010.04.008

Ioffe G, Nefedova T, Zaslavsky I. 2004. From Spatial Continuity to Fragmentation: The Case of Russian Farming. Annals of the Association of American Geographers 94 (4): 913-943 DOI: 10.1111/j.14678306.2004.00441.x

Ivanov MM, Konoplev AV, Walling DE, Konstantinov EA, Gurinov AL, Ivanova NN, Kuzmenkova NV, Tsyplenkov AS, Ivanov MA, Golosov VN. 2021. Using reservoir sediment deposits to determine the longerterm fate of chernobyl-derived $137 \mathrm{Cs}$ fallout in the fluvial system.Environmental Pollution 274: 116588 DOI: $10.1016 /$ j.envpol.2021.116588

Jackson JE. 2003. A user's guide to principal components . Wiley-Interscience: Hoboken, N.J. 
Jeffery ML, Yanites BJ, Poulsen CJ, Ehlers TA. 2014. Vegetation-precipitation controls on Central Andean topography. Journal of Geophysical Research: Earth Surface 119 (6): 1354-1375 DOI: 10.1002/2013JF002919

Jennings KS, Winchell TS, Livneh B, Molotch NP. 2018. Spatial variation of the rain-snow temperature threshold across the Northern Hemisphere.Nature Communications 9 (1): 1148 DOI: 10.1038/s41467-018$03629-7$

Kasper D, Fernandes Amaral JH, Rider Forsberg B. 2018. The effect of filter type and porosity on total suspended sediment determinations.Analytical Methods 10 (46): 5532-5539 DOI: 10.1039/C8AY02134A

Kennedy VC, Zellweger GW, Jones BF. 1974. Filter pore-size effects on the analysis of Al, Fe, Mn, and Ti in water. Water Resources Research 10 (4): 785-790 DOI: https://doi.org/10.1029/WR010i004p00785

Kireeva M, Frolova N, Rets E, Samsonov T, Entin A, Kharlamov M, Telegina E, Povalishnikova E. 2020. Evaluating climate and water regime transformation in the European part of Russia using observation and reanalysis data for the 1945-2015 period. International Journal of River Basin Management 18 (4): 491-502 DOI: $10.1080 / 15715124.2019 .1695258$

Kondolf GM. 1997. Hungry Water: Effects of Dams and Gravel Mining on River Channels. Environmental Management 21 (4): 533-551 DOI: 10.1007/s002679900048

Kundzewicz ZW, Robson AJ. 2004. Change detection in hydrological records - a review of the methodology / Revue méthodologique de la détection de changements dans les chroniques hydrologiques.Hydrological Sciences Journal 49 (1): 7-19 DOI: 10.1623/hysj.49.1.7.53993

Lesiv M, Schepaschenko D, Moltchanova E, Bun R, Dürauer M, Prishchepov AV, Schierhorn F, Estel S, Kuemmerle T, Alcántara C, et al. 2018. Spatial distribution of arable and abandoned land across former Soviet Union countries. Scientific Data 5 (1): 180056 DOI: 10.1038/sdata.2018.56

Li L, Ni J, Chang F, Yue Y, Frolova N, Magritsky D, Borthwick AGL, Ciais P, Wang Y, Zheng C, et al. 2020. Global trends in water and sediment fluxes of the world's large rivers. Science Bulletin 65(1): $62-69$ DOI: $10.1016 /$ j.scib.2019.09.012

Liuzzo L, Bono E, Sammartano V, Freni G. 2017. Long-term temperature changes in Sicily, Southern Italy. Atmospheric Research198 : 44-55 DOI: 10.1016/j.atmosres.2017.08.007

Lizaga I, Quijano L, Palazón L, Gaspar L, Navas A. 2018. Enhancing Connectivity Index to Assess the Effects of Land Use Changes in a Mediterranean Catchment. Land Degradation 83 Development 29 (3): 663-675 DOI: https://doi.org/10.1002/ldr.2676

Marks M. 2020. ChangePointTaylor: Identify Changes in Mean . Available at: https://CRAN.Rproject.org $/$ package $=$ ChangePointTaylor

Mavromatis T, Stathis D. 2011. Response of the water balance in Greece to temperature and precipitation trends. Theoretical and Applied Climatology 104 (1): 13-24 DOI: 10.1007/s00704-010-0320-9

Moatar F, Person G, Meybeck M, Coynel A, Etcheber H, Crouzet P. 2006. The influence of contrasting suspended particulate matter transport regimes on the bias and precision of flux estimates. Science of The Total Environment 370 (2): 515-531 DOI: 10.1016/j.scitotenv.2006.07.029

Molnar P, Anderson RS, Anderson SP. 2007. Tectonics, fracturing of rock, and erosion. Journal of Geophysical Research: Earth Surface112 (F3) DOI: 10.1029/2005JF000433

Montanher OC, Novo EML de M, Filho EE de S. 2018. Temporal trend of the suspended sediment transport of the Amazon River (1984-2016).Hydrological Sciences Journal 63 (13-14): 1901-1912 DOI: 10.1080/02626667.2018.1546387

Montgomery DR. 2007. Soil erosion and agricultural sustainability.Proceedings of the National Academy of Sciences 104(33): 13268-13272 DOI: 10.1073/pnas.0611508104 
Moore RD, Fleming SW, Menounos B, Wheate R, Fountain A, Stahl K, Holm K, Jakob M. 2009. Glacier change in western North America: influences on hydrology, geomorphic hazards and water quality. Hydrological Processes 23 (1): 42-61 DOI: https://doi.org/10.1002/hyp.7162

Onyutha C. 2016. Statistical Uncertainty in Hydrometeorological Trend Analyses. Advances in Meteorology 2016 : e8701617 DOI: 10.1155/2016/8701617

Oost KV, Quine TA, Govers G, Gryze SD, Six J, Harden JW, Ritchie JC, McCarty GW, Heckrath G, Kosmas C, et al. 2007. The Impact of Agricultural Soil Erosion on the Global Carbon Cycle. Science 318 (5850): 626-629 DOI: 10.1126/science.1145724

Oswood MW, Milner AM, Irons JG. 1992. Climate Change and Alaskan Rivers and Streams. In Global Climate Change and Freshwater Ecosystems, Firth P, , Fisher SG (eds).Springer: New York, NY; 192-210. DOI: 10.1007/978-1-4612-2814-1_9

Pettitt AN. 1979. A Non-Parametric Approach to the Change-Point Problem.Journal of the Royal Statistical Society: Series C (Applied Statistics) 28 (2): 126-135 DOI: https://doi.org/10.2307/2346729

Poesen J. 2018. Soil erosion in the Anthropocene: Research needs: Soil erosion in the Anthropocene. Earth Surface Processes and Landforms 43 (1): 64-84 DOI: 10.1002/esp.4250

Portenga EW, Bierman PR. 2011. Understanding Earth's eroding surface with 10Be. GSA Today 21 (8): 4-10 DOI: 10.1130/G111A.1

Raup B, Racoviteanu A, Khalsa SJS, Helm C, Armstrong R, Arnaud Y. 2007. The GLIMS geospatial glacier database: A new tool for studying glacier change. Global and Planetary Change 56 (1-2): 101-110 DOI: 10.1016/j.gloplacha.2006.07.018

Rets EP, Durmanov IN, Kireeva MB, Smirnov AM, Popovnin VV. 2020. Past 'peak water' in the North Caucasus: deglaciation drives a reduction in glacial runoff impacting summer river runoff and peak discharges.Climatic Change DOI: 10.1007/s10584-020-02931-y

Rets EP, Dzhamalov RG, Kireeva MB, Frolova NL, Durmanov IN, Telegina AA, Telegina EA, Grigoriev VYu. 2018. Recent trends of river runoff in the North Caucasus. GEOGRAPHY, ENVIRONMENT, SUSTAINABILITY 11 (3): 61-70 DOI: 10.24057/2071-9388-2018-11-3-61-70

Rodrigo-Comino J, Martínez-Hernández C, Iserloh T, Cerdà A. 2018. Contrasted Impact of Land Abandonment on Soil Erosion in Mediterranean Agriculture Fields. Pedosphere 28 (4): 617-631 DOI: 10.1016/S10020160(17)60441-7

Salerno F, Thakuri S, D'Agata C, Smiraglia C, Manfredi EC, Viviano G, Tartari G. 2012. Glacial lake distribution in the Mount Everest region: Uncertainty of measurement and conditions of formation. Global and Planetary Change 92-93 : 30-39 DOI: 10.1016/j.gloplacha.2012.04.001

Shahgedanova M, Popovnin V, Aleynikov A, Petrakov D, Stokes CR. 2007. Long-term change, interannual and intra-seasonal variability in climate and glacier mass balance in the central Greater Caucasus, Russia.Annals of Glaciology 46 : 355-361 DOI: 10.3189/172756407782871323

Solomina O, Bushueva I, Dolgova E, Jomelli V, Alexandrin M, Mikhalenko V, Matskovsky V. 2016. Glacier variations in the Northern Caucasus compared to climatic reconstructions over the past millennium. Global and Planetary Change 140 : 28-58 DOI: 10.1016/j.gloplacha.2016.02.008

Steegen A, Govers G. 2001. Correction factors for estimating suspended sediment export from loess catchments. Earth Surface Processes and Landforms 26 (4): 441-449 DOI: https://doi.org/10.1002/esp.196

Syvitski JPM, Milliman JD. 2007. Geology, Geography, and Humans Battle for Dominance over the Delivery of Fluvial Sediment to the Coastal Ocean. The Journal of Geology 115 (1): 1-19 DOI: 10.1086/509246 
Syvitski JPM, Vörösmarty CJ, Kettner AJ, Green P. 2005. Impact of Humans on the Flux of Terrestrial Sediment to the Global Coastal Ocean.Science 308 (5720): 376-380 DOI: 10.1126/science.1109454

Tarolli P. 2016. Humans and the Earth's surface: Humans and the Earth's surface. Earth Surface Processes and Landforms 41 (15): 2301-2304 DOI: 10.1002/esp.4059

Taylor WA. 2000. Change-point analysis: a powerful new tool for detecting changes

Tielidze LG, Wheate RD. 2018. The Greater Caucasus Glacier Inventory (Russia, Georgia and Azerbaijan). The Cryosphere 12 (1): 81-94 DOI: https://doi.org/10.5194/tc-12-81-2018

Toropov PA, Aleshina MA, Grachev AM. 2019. Large-scale climatic factors driving glacier recession in the Greater Caucasus, 20th-21st century.International Journal of Climatology 39 (12): 4703-4720 DOI: https://doi.org/10.1002/joc.6101

Trimble SW. 1999. Decreased Rates of Alluvial Sediment Storage in the Coon Creek Basin, Wisconsin, 1975-93. Science 285(5431): 1244-1246 DOI: 10.1126/science.285.5431.1244

Tsyplenkov A, Vanmaercke M, Collins AL, Kharchenko S, Golosov V. 2021. Elucidating suspended sediment dynamics in a glacierized catchment after an exceptional erosion event: The Djankuat catchment, Caucasus Mountains, Russia. CATENA 203 : 105285 DOI: 10.1016/j.catena.2021.105285

Valderrama Murillo PA, Vilca O. 2012. Dinámica e implicancia del aluvión de la laguna 513, Cordillera Blanca, Ancash, Perú. Repositorio Institucional INGEMMET Available at: https://repositorio.ingemmet.gob.pe/handle/20.500.12544/692 [Accessed 1 June 2021]

Vanacker V, Bellin N, Molina A, Kubik PW. 2014. Erosion regulation as a function of human disturbances to vegetation cover: a conceptual model.Landscape Ecology 29 (2): 293-309 DOI: 10.1007/s10980-013-9956-z

Vanmaercke M, Ardizzone F, Rossi M, Guzzetti F. 2017. Exploring the effects of seismicity on landslides and catchment sediment yield: An Italian case study. Geomorphology 278 : 171-183 DOI: 10.1016/j.geomorph.2016.11.010

Vanmaercke M, Kettner AJ, Eeckhaut MVD, Poesen J, Mamaliga A, Verstraeten G, Rãdoane M, Obreja F, Upton P, Syvitski JPM, et al. 2014a. Moderate seismic activity affects contemporary sediment yields.Progress in Physical Geography: Earth and Environment 38(2): 145-172 DOI: 10.1177/0309133313516160

Vanmaercke M, Obreja F, Poesen J. 2014b. Seismic controls on contemporary sediment export in the Siret river catchment, Romania.Geomorphology 216 : 247-262 DOI: 10.1016/j.geomorph.2014.04.008

Vanmaercke M, Poesen J, Govers G, Verstraeten G. 2015. Quantifying human impacts on catchment sediment yield: A continental approach.Global and Planetary Change 130 : 22-36 DOI: 10.1016/j.gloplacha.2015.04.001

Vanmaercke M, Poesen J, Maetens W, de Vente J, Verstraeten G. 2011. Sediment yield as a desertification risk indicator. Science of The Total Environment 409 (9): 1715-1725 DOI: 10.1016/j.scitotenv.2011.01.034

de Vente J, Poesen J, Verstraeten G, Govers G, Vanmaercke M, Van Rompaey A, Arabkhedri M, Boix-Fayos C. 2013. Predicting soil erosion and sediment yield at regional scales: Where do we stand?Earth-Science Reviews 127 : 16-29 DOI: 10.1016/j.earscirev.2013.08.014

Verhaegen Y, Huybrechts P, Rybak O, Popovnin VV. 2020. Modelling the evolution of Djankuat Glacier, North Caucasus, from 1752 until 2100 CE. The Cryosphere 14 (11): 4039-4061 DOI: 10.5194/tc-14-4039-2020

Walling DE. 1983. The sediment delivery problem. Journal of Hydrology 65 (1): 209-237 DOI: 10.1016/00221694(83)90217-2

Walling DE. 1988. Erosion and sediment yield research — Some recent perspectives. Journal of Hydrology 100 (1): 113-141 DOI: 10.1016/0022-1694(88)90183-7 
Walling DE, Fang D. 2003. Recent trends in the suspended sediment loads of the world's rivers. Global and Planetary Change 39(1): 111-126 DOI: 10.1016/S0921-8181(03)00020-1

Waters CN, Zalasiewicz J, Summerhayes C, Barnosky AD, Poirier C, Gałuszka A, Cearreta A, Edgeworth M, Ellis EC, Ellis M, et al. 2016. The Anthropocene is functionally and stratigraphically distinct from the Holocene. Science 351 (6269) DOI: 10.1126/science.aad2622

Waters CN, Zalasiewicz JA, Williams M, Ellis MA, Snelling AM. 2014. A stratigraphical basis for the Anthropocene? Geological Society, London, Special Publications 395 (1): 1-21 DOI: 10.1144/SP395.18

Wei X, Zhang M. 2010. Quantifying streamflow change caused by forest disturbance at a large spatial scale: A single watershed study. Water Resources Research 46 (12) DOI: https://doi.org/10.1029/2010WR009250

Williams GP, Rosgen DL. 1989. Measured total sediment loads (suspended loads and bedloads) for 93 United States streams. 89-67. U.S. Geological Survey. DOI: 10.3133/ofr8967

Zarfl C, Lumsdon AE, Berlekamp J, Tydecks L, Tockner K. 2015. A global boom in hydropower dam construction. Aquatic Sciences 77(1): 161-170 DOI: 10.1007/s00027-014-0377-0

Zhang F, Shi X, Zeng C, Wang L, Xiao X, Wang G, Chen Y, Zhang H, Lu X, Immerzeel W. 2020. Recent stepwise sediment flux increase with climate change in the Tuotuo River in the central Tibetan Plateau. Science Bulletin 65 (5): 410-418 DOI: 10.1016/j.scib.2019.12.017

Zhang S, Lu XX, Higgitt DL, Chen C-TA, Han J, Sun H. 2008. Recent changes of water discharge and sediment load in the Zhujiang (Pearl River) Basin, China. Global and Planetary Change 60 (3): 365-380 DOI: $10.1016 /$ j.gloplacha.2007.04.003

Tables

Table 1. General information about gauging stations of the upper Terek basin

\begin{tabular}{|c|c|c|}
\hline Gauging station & Label & $\operatorname{Area}(\mathrm{A}), \mathrm{km}^{2}$ \\
\hline $\begin{array}{l}\text { Gauging station altitude }<500 \mathbf{m} \\
\text { r.Baksan - st.Prokhladnava }\end{array}$ & $\begin{array}{l}\text { Gauging station altitude }<500 \mathrm{~m} \\
\text { Bak-Pr }\end{array}$ & $\begin{array}{l}\text { Gauging station altitude }< \\
6800\end{array}$ \\
\hline r.Malka - kh.Pavlogradskiy & Mal-Pa & 2000 \\
\hline r.Malka - st.Prokhladnaya & Mal-Pr & 9820 \\
\hline r.Sunzha - s.Braguny & Sun-Br & 12200 \\
\hline r.Sunzha - g.Groznyy & Sun-Gr & 4820 \\
\hline r.Terek - st.Chernoyarskaya & Ter-Ch & 19600 \\
\hline r.Terek - s.El'khotovo & Ter-El & 6490 \\
\hline r.Terek - st-tsa. Kargalinskaya & Ter-Ka & 37400 \\
\hline r.Terek - st.Kotlyarevskaya & Ter-Ko & 8920 \\
\hline r.Terek - g. Mozdok & Ter-Mo & 20600 \\
\hline r.Terek - s.Stepnoye & Ter-St & 35400 \\
\hline $\begin{array}{l}\text { Gauging station altitude: } 500-1000 \mathrm{~m} \\
\text { r.Ardon - s.Tamisk }\end{array}$ & $\begin{array}{l}\text { Gauging station altitude: } 500-1000 \mathrm{~m} \\
\text { Ard-Ta }\end{array}$ & $\begin{array}{l}\text { Gauging station altitude: } \\
1080\end{array}$ \\
\hline r.Baksan - s.Zayukovo & Bak-Za & 2100 \\
\hline r.Belaya - s.Kora - Ursdon & Bel-Ko & 304 \\
\hline r.Cherek Balkarskiy - pos.Babugent & Che-Ba & 695 \\
\hline r.Cherek - s.Sovet·skoye & Che-So & 1350 \\
\hline r.Chegem - s.Nizhniy Chegem & Cheg-Nc & 739 \\
\hline r.Fiagdon - s.Gusra & Fia-Gu & 398 \\
\hline r.Fiagdon - s.Tagardon & Fia-Ta & 410 \\
\hline r.Gizel'don - s.Gizel' & Giz-Gi & 410 \\
\hline r.Kambileyevka - s.Ol'ginskoye & Kam-Ol & 359 \\
\hline
\end{tabular}




\begin{tabular}{lll}
\hline Gauging station & Label & Area $\mathbf{( A )} \mathbf{~ k m}^{\mathbf{2}}$ \\
\hline r.Malka - s.Kamennomost·skoye & Mal-Ka & 1540 \\
r.Malka - s.Khabaz & Mal-Kh & 1080 \\
r.Terek - g. Vladikavkaz & Ter-Vl & 1490 \\
r.Urukh - s.Khaznidon & Uru-Kh & 1150 \\
Gauging station altitude > 1000 $\mathbf{m}$ & Gauging station altitude > $\mathbf{1 0 0 0} \mathbf{m}$ & Gauging station altitude > \\
r.Ardon - s.Nizhniy Zaromag & Ard-Nz & 552 \\
r.Chegem - s.Verkhniy Chegem & Cheg-Vc & 433 \\
r.Fiagdon - s.Verkhniy Fiagdon & Fia-Vf & 238 \\
r.Genaldon - s.Tmenikau & Gen-Tm & 56 \\
r.Gizel'don - s.Dargavs & Giz-Da & 129 \\
r.Gizel'don - s.Verkhnyaya Koban' & Giz-Vk & 160 \\
r.Terek - s.Kazbegi & Ter-Kaz & 778 \\
r.Terek - s.Nizhniy Lars & Ter-Nl & 1010 \\
\hline
\end{tabular}

Table 2. Trends in annual suspended sediment load (SSL), cropland, forest, and glaciated areas change. A trend slope is expressed in percent change per year and $95 \%$ confidence interval presented in square brackets. The slopes with p-values less than 0.05 are highlighted in bold.

\begin{tabular}{|c|c|c|}
\hline Label & $1925-2018$ & $1987-2015$ \\
\hline & $\operatorname{SSL}^{1}$ & $\operatorname{SSL}^{1}$ \\
\hline Gauging station altitude $<500 \mathrm{~m}$ & Gauging station altitude $<500 \mathrm{~m}$ & Gauging station altitude $<$ \\
\hline Bak-Pr & $-1.6[-2.08 ;-1.16]$ & \\
\hline Mal-Pa & $0.407[0.0338 ; 0.78]$ & \\
\hline Mal-Pr & $-1.22[-1.4 ;-1.05]$ & $-0.206[-1.39 ; 1.08]$ \\
\hline Sun-Br & $-2.02[-2.42 ;-1.63]$ & \\
\hline Sun-Gr & $-2.19[-2.67 ;-1.7]$ & \\
\hline Ter-Ch & $-1.72[-2.23 ;-1.24]$ & \\
\hline Ter-El & $-1.14[-1.56 ;-0.738]$ & \\
\hline Ter-Ka & $-2.3[-2.71 ;-1.88]$ & \\
\hline Ter-Ko & $0.344[0.16 ; 0.53]$ & $-14.9[-17.7 ;-12.1]$ \\
\hline Ter-Mo & $-0.765[-1.2 ;-0.347]$ & \\
\hline Ter-St & $-1.74[-2.07 ;-1.4]$ & \\
\hline $\begin{array}{l}\text { Gauging station altitude: } 500-1000 \mathrm{~m} \\
\text { Ard-Ta }\end{array}$ & $\begin{array}{l}\text { Gauging station altitude: } \mathbf{5 0 0 - 1 0 0 0 ~} \mathbf{~ m} \\
-0.895[-1.17 ;-0.605]\end{array}$ & Gauging station altitude: 5 \\
\hline Bak-Za & $-0.336[-0.686 ;-0.00415]$ & \\
\hline Bel-Ko & $-1.82[-2.06 ;-1.59]$ & $-5.03[-6.6 ;-3.32]$ \\
\hline Che-Ba & $-1.01[-1.24 ;-0.808]$ & $-6.92[-9.01 ;-4.96]$ \\
\hline Che-So & $-0.318[-0.753 ; 0.0961]$ & \\
\hline Cheg-Nc & $-1.03[-1.26 ;-0.811]$ & $-2.54[-4.46 ;-0.716]$ \\
\hline Fia-Gu & $-1.09[-1.32 ;-0.871]$ & \\
\hline Fia-Ta & $-1.47[-1.63 ;-1.29]$ & $0.53[-1.64 ; 2.59]$ \\
\hline Giz-Gi & $-21.4[-27.9 ;-14.2]$ & $-23.8[-32.5 ;-14.8]$ \\
\hline Kam-Ol & $-1.25[-1.54 ;-0.967]$ & $-5.55[-8.7 ;-2.49]$ \\
\hline Mal-Ka & $-0.674[-0.87 ;-0.475]$ & $-4.54[-6.24 ;-2.8]$ \\
\hline Mal-Kh & $-0.614[-1.08 ;-0.14]$ & \\
\hline Ter-Vl & $0.259[0.0261 ; 0.494]$ & $-18.7[-22.3 ;-15.2]$ \\
\hline Uru-Kh & $-0.117[-0.48 ; 0.239]$ & $-6.03[-7.86 ;-4.26]$ \\
\hline $\begin{array}{l}\text { Gauging station altitude }>1000 \mathrm{~m} \\
\text { Ard-Nz }\end{array}$ & $\begin{array}{l}\text { Gauging station altitude }>1000 \mathbf{m} \\
-1.65[-2.1 ;-1.2]\end{array}$ & Gauging station altitude $>$ \\
\hline
\end{tabular}




\begin{tabular}{lll}
\hline Label & $\mathbf{1 9 2 5 - 2 0 1 8}$ & $\mathbf{1 9 8 7 - 2 0 1 5}$ \\
\hline Cheg-Vc & $-0.41[-0.852 ; 0.049]$ & $29.3[21 ; 37.4]$ \\
Fia-Vf & $13.1[9.75 ; 16.4]$ & \\
Gen-Tm & $-0.408[-0.837 ; 0.0188]$ & \\
Giz-Da & $-0.198[-0.686 ; 0.296]$ & \\
Giz-Vk & $-0.689[-1.11 ;-0.268]$ & \\
Ter-Kaz & $0.607[0.269 ; 0.946]$ & \\
Ter-Nl & $-0.497[-0.938 ;-0.0641]$ & \\
\hline
\end{tabular}

${ }^{1}$ SSL is not available for the whole observation period.

Table 3 . Significant changes in annual average SSDestimated with Taylor's (2000) and Pettitt's (1979) approach. Transition years with Pettitt's p-value $<0.05$ are in bold.

\begin{tabular}{llllll}
\hline & Taylor, 2000 & Taylor, 2000 & Taylor, 2000 & Pettitt, 1979 & Pettitt, 1979 \\
\hline Label & Year & Confidence interval & Confidence level & Year & p-value \\
Ard-Ta & 1968 & $1954-1968$ & $98.9 \%$ & 1992 & $\mathbf{3 . 1 7 E - 0 9}$ \\
& 1981 & $1978-1987$ & $83.4 \%$ & & \\
& 1993 & $1991-1994$ & $100.0 \%$ & & \\
& 2012 & $2003-2012$ & $91.8 \%$ & 2009 & 0.135 \\
Bel-Ko & 2010 & $1996-2010$ & $91.5 \%$ & 1977 & $\mathbf{0 . 0 0 0 0 8}$ \\
Che-Ba & 1990 & $1977-1992$ & $98.3 \%$ & 1989 & 0.126 \\
Cheg-Nc & 1988 & $1967-1989$ & $99.5 \%$ & 1984 & $\mathbf{2 . 8 2 E - 0 8}$ \\
Fia-Ta & 1968 & $1952-1968$ & $96.2 \%$ & & \\
& 1977 & $1974-1977$ & $92.7 \%$ & & \\
Kam-Ol & 1985 & $1985-1989$ & $91.8 \%$ & & \\
& 1981 & $1971-1971$ & $98.8 \%$ & & \\
& 1994 & $1981-1985$ & $99.2 \%$ & & \\
Mal-Ka & 1966 & $1992-1996$ & $100.0 \%$ & & \\
& 1984 & $1964-1970$ & $97.6 \%$ & & \\
Sun-Br & 1990 & $1984-1988$ & $86.4 \%$ & & \\
& 1958 & $1956-1961$ & $99.2 \%$ & 1989 & \\
Uru-Kh & 1994 & $1983-2000$ & $99.6 \%$ & & \\
& 1983 & $1980-1993$ & $93.1 \%$ & & \\
& 2005 & $1993-2006$ & $87.8 \%$ & & \\
\hline
\end{tabular}

Table 4. Suspended sediment discharge reduction in the upper Terek basin. Comparison of extrapolated cumulative sediment discharge till $2018\left(S S D_{C}, \mathrm{~kg} \cdot \mathrm{s}^{-1}\right)$ and observed cumulative sediment discharge till 2018 $\left(S S D_{O}, \mathrm{~kg}^{*} \mathrm{~s}^{-1}\right)$.

\begin{tabular}{|c|c|c|c|c|c|}
\hline Label & Transition year & $\mathbf{S S D}_{\mathbf{C}}$ & $\mathrm{SSD}_{\mathrm{O}}$ & $\mathrm{SSD}_{\mathrm{C}}-\mathrm{SSD}_{\mathrm{O}}$ & $100 \times\left(\mathrm{SSD}_{\mathrm{C}^{-}} \mathrm{SSD}_{\mathrm{O}}\right) / \mathrm{SSD}_{\mathrm{C}}$ \\
\hline Ard-Ta & 1992 & 1244 & 838 & 407 & $33 \%$ \\
\hline Bel-Ko & 2009 & 105 & 93.3 & 11.9 & $11 \%$ \\
\hline Che-Ba & 1989 & 981 & 766 & 215 & $22 \%$ \\
\hline Cheg-Nc & 1987 & 383 & 310 & 72.8 & $19 \%$ \\
\hline Fia-Ta & 1984 & 219 & 139 & 80.7 & $37 \%$ \\
\hline Kam-Ol & 1993 & 111 & 63.5 & 47.9 & $43 \%$ \\
\hline Mal-Ka & 1989 & 391 & 327 & 64.3 & $16 \%$ \\
\hline
\end{tabular}




\begin{tabular}{llllll}
\hline Label & Transition year & SSD $_{\mathbf{C}}$ & SSD $_{\mathbf{O}}$ & SSD $_{\mathbf{C}}-\mathbf{S S D}_{\mathbf{O}}$ & $\mathbf{1 0 0} \times\left(\mathbf{S S D}_{\mathbf{C}}-\mathbf{S S D}_{\mathbf{O}}\right) / \mathbf{S S D}_{\mathbf{C}}$ \\
\hline Sun- $\mathrm{Br}$ & 1993 & 14336 & 11615 & 2722 & $19 \%$ \\
Uru-Kh & 2005 & 576 & 504 & 72 & $12 \%$ \\
\hline
\end{tabular}

Table 5. Impact of precipitation and other factors on suspended sediment discharge decline in the upper Terek basin.

\begin{tabular}{|c|c|c|c|c|c|c|c|c|}
\hline \multirow[t]{2}{*}{ Label } & \multirow[t]{2}{*}{ Period } & \multirow[t]{2}{*}{$\begin{array}{l}\mathrm{SSD}_{\mathrm{O}} \\
\mathrm{kg} \cdot \mathrm{s}^{-1}\end{array}$} & \multirow[t]{2}{*}{$\begin{array}{l}\mathrm{SSD}_{\mathrm{C}} \\
\mathrm{kg} \cdot \mathrm{s}^{-1}\end{array}$} & $\mathrm{SSD}_{\mathrm{O}}$ & $\mathrm{SSD}_{\mathrm{O}}$ & \multicolumn{3}{|c|}{$\begin{array}{r}\text { Other } \\
\text { PrecipitatioRrecipitatiofactors }\end{array}$} \\
\hline & & & & $\mathrm{kg} \cdot \mathrm{s}^{-1}$ & $\%$ & $\mathrm{~kg} \cdot \mathrm{s}^{-1}$ & $\%$ & $\mathrm{~kg} \cdot \mathrm{s}^{-1}$ \\
\hline \multirow[t]{2}{*}{ Ard-Ta } & $\begin{array}{l}\text { before } \\
1992\end{array}$ & 21.4 & 21.4 & & & & & \\
\hline & $\begin{array}{l}\text { after } \\
1992\end{array}$ & 3.45 & 19 & 17.9 & $84 \%$ & 2.38 & $13 \%$ & 15.5 \\
\hline \multirow[t]{2}{*}{ Bel-Ko } & $\begin{array}{l}\text { before } \\
2009\end{array}$ & 1.71 & 1.75 & & & & & \\
\hline & $\begin{array}{l}\text { after } \\
2009\end{array}$ & 0.471 & 1.59 & 1.24 & $72 \%$ & 0.119 & $10 \%$ & 1.12 \\
\hline \multirow[t]{2}{*}{ Che-Ba } & $\begin{array}{l}\text { before } \\
1989\end{array}$ & 16.3 & 16.4 & & & & & \\
\hline & $\begin{array}{l}\text { after } \\
1989\end{array}$ & 8.41 & 15.7 & 7.9 & $48 \%$ & 0.616 & $8 \%$ & 7.29 \\
\hline \multirow[t]{2}{*}{$\begin{array}{l}\text { Cheg- } \\
\mathrm{Nc}\end{array}$} & $\begin{array}{l}\text { before } \\
1987\end{array}$ & 6.46 & 6.4 & & & & & \\
\hline & $\begin{array}{l}\text { after } \\
1987\end{array}$ & 3.76 & 6.17 & 2.69 & $42 \%$ & 0.285 & $11 \%$ & 2.41 \\
\hline \multirow[t]{2}{*}{ Fia-Ta } & $\begin{array}{l}\text { before } \\
1984\end{array}$ & 3.95 & 3.93 & & & & & \\
\hline & $\begin{array}{l}\text { after } \\
1984\end{array}$ & 0.942 & 3.33 & 3.01 & $76 \%$ & 0.617 & $21 \%$ & 2.39 \\
\hline \multirow[t]{2}{*}{$\begin{array}{l}\text { Kam- } \\
\mathrm{Ol}\end{array}$} & $\begin{array}{l}\text { before } \\
1993\end{array}$ & 2.98 & 3.05 & & & & & \\
\hline & $\begin{array}{l}\text { after } \\
1993\end{array}$ & 0.99 & 2.87 & 1.99 & $67 \%$ & 0.108 & $5 \%$ & 1.88 \\
\hline \multirow[t]{2}{*}{$\begin{array}{l}\text { Mal- } \\
\text { Ka }\end{array}$} & $\begin{array}{l}\text { before } \\
1989\end{array}$ & 6.6 & 6.64 & & & & & \\
\hline & $\begin{array}{l}\text { after } \\
1989\end{array}$ & 3.98 & 6.17 & 2.62 & $40 \%$ & 0.439 & $17 \%$ & 2.18 \\
\hline \multirow[t]{2}{*}{ Sun-Br } & $\begin{array}{l}\text { before } \\
1993\end{array}$ & 242 & 243 & & & & & \\
\hline & $\begin{array}{l}\text { after } \\
1993\end{array}$ & 116 & 224 & 126 & $52 \%$ & 18.1 & $14 \%$ & 108 \\
\hline \multirow[t]{2}{*}{$\begin{array}{l}\text { Uru- } \\
\text { Kh }\end{array}$} & $\begin{array}{l}\text { before } \\
2005\end{array}$ & 16.1 & 15.7 & & & & & \\
\hline & $\begin{array}{l}\text { after } \\
2005\end{array}$ & 9.12 & 15.3 & 6.95 & $43 \%$ & 0.755 & $11 \%$ & 6.19 \\
\hline
\end{tabular}


Table 6. Trend comparison from various studies. Suspended sediment load (SSL $\left[t \cdot \mathrm{yr}^{-1}\right]$, this study), suspended sediment discharge from Gusarov et al. (2021) (SSD $\left[\mathrm{kg}^{*} \mathrm{~s}^{-1}\right]$ ), and water discharge characteristics $\left[\mathrm{m}^{3 *} \mathrm{~s}^{-1}\right]$ from Rets et al. (2020): change in mean monthly discharges in June, July, August $\left(\mathrm{Q}_{\mathrm{june}}, \mathrm{Q}_{\mathrm{july}}\right.$, $\left.\mathrm{Q}_{\text {aug }}\right)$, and change in annual peak discharge $\left(\mathrm{Q}_{\max }\right)$.

\begin{tabular}{lllllll}
\hline Source & This study & (Gusarov et al., 2021) & (Rets et al., 2020) & (Rets et al., 2020) & (Rets et al., 2020) & (Rets \\
\hline Time period & $\mathbf{1 9 2 5 - 2 0 1 8}$ & $\mathbf{1 9 6 3 - 2 0 1 7}$ & $\mathbf{1 9 4 5 - 2 0 1 8}$ & $\mathbf{1 9 4 5 - 2 0 1 8}$ & $\mathbf{1 9 4 5 - 2 0 1 8}$ & $\mathbf{1 9 4 5}$ \\
Label & SSL & SSD & $\mathbf{Q}_{\max }$ & $\mathbf{Q}_{\mathbf{j u n e}}$ & $\mathbf{Q}_{\mathbf{j u l y}}$ & $\mathbf{Q}_{\mathbf{a u g}}$ \\
Ter-Vl & 0.207 & - & -0.41 & 0.15 & -0.07 & -0.3 \\
Ter-Ko & 0.277 & -1.13 & 0.13 & 0.17 & -0.07 & -0.1 \\
Kam-Ol & -0.998 & -0.309 & 0.27 & 0.58 & 0.5 & 0.37 \\
Uru-Kh & -0.094 & - & 0.11 & 0.38 & 0.17 & 0.06 \\
Mal-Ka & -0.539 & - & -0.05 & 0.54 & 0.29 & 0.24 \\
Mal-Pr & -0.974 & -0.855 & -0.01 & 0.34 & 0.08 & -0.17 \\
Bak-Za & -0.266 & - & 0.09 & 0.19 & 0.07 & -0.06 \\
Cheg-Nc & -0.829 & -0.691 & - & - & - & -0.01 \\
Che-Ba & -0.811 & -1.15 & -0.44 & 0.14 & & -0.06 \\
\hline
\end{tabular}

\section{Figure captions}

Figure 1. Map of the upper Terek basin with topography, glacierized areas, cropland, and river network. The main 33 gauging stations considered in this study are represented with dots. See Table 1 for label transcriptions. The extent of the glaciers is shown as of 2011-2016 (Raup et al. , 2007), cropland as of 2015 (Buchneret al. , 2020)

Figure 2. Mean monthly values of suspended sediment discharge $\left(S S D, \mathrm{~kg} \cdot \mathrm{s}^{-1}\right)$ measured at the gauging stations. Colored shaded areas represent the range corresponding to +- standard error. Mean values and standard errors are computed over the entire observation period. The length of the period is shown in brackets.

Figure 3 . Suspended sediment load change time series. The black line displays the time series with the uncertainty envelope. The red line corresponds to a linear trend.

Figure 4. CUSUM charts for the mean annual SSD. The transition years are indicated with grey (Taylor, 2000) and red (Pettitt, 1979) lines depending on the changepoint test.

Figure 5. Double mass curves of precipitation-sediment during 1958-2018 in the upper Terek basin. See Table 4 for changepoint location (i.e., transition year). The Red dashed line shows an extrapolated cumulative sediment discharge.

Figure 6. Density plots of trend magnitudes for SSL $\left(\% \mathrm{yr}^{-1}\right)$. Here we plotted randomly simulated SSL trend values for the whole observation period (see Section 2.6 ). The vertical dashed lines indicate trends with the highest kernel density, and a black vertical line highlights the zero trend.

Figure 7. Scatter plots of the suspended sediment load trends (\% change per year) versus the catchment area (a), glacier area in 1986 (b), cropland, and forest area in 1987 (c, d). Circles indicate the mean simulated SSL trend values, while error bars indicate the $95 \%$ confidence interval (see Section 2.6).

Figure 8. Spearman's rank correlation coefficients (Spearman r) between the estimated SSL trend values (Eq.(3)) and the considered potential controlling factors for different altitude zones. Each boxplot shows the distribution of 1000 Spearman r-values, where each value was obtained by randomly simulating a set of SSL trend values and calculating the correlation between these values and the indicated variable (see Section 2.6). Thus, whiskers of each boxplot represent 1.5 times the difference between the $75 \%$ and $25 \%$ quantile. Altitude is the actual height of the gauging station above the mean sea level; Area is a catchment area; 
Cropland and forest represented their fraction in a catchment in 1987; Glacier stood for glacier fraction in a catchment in 1986 .
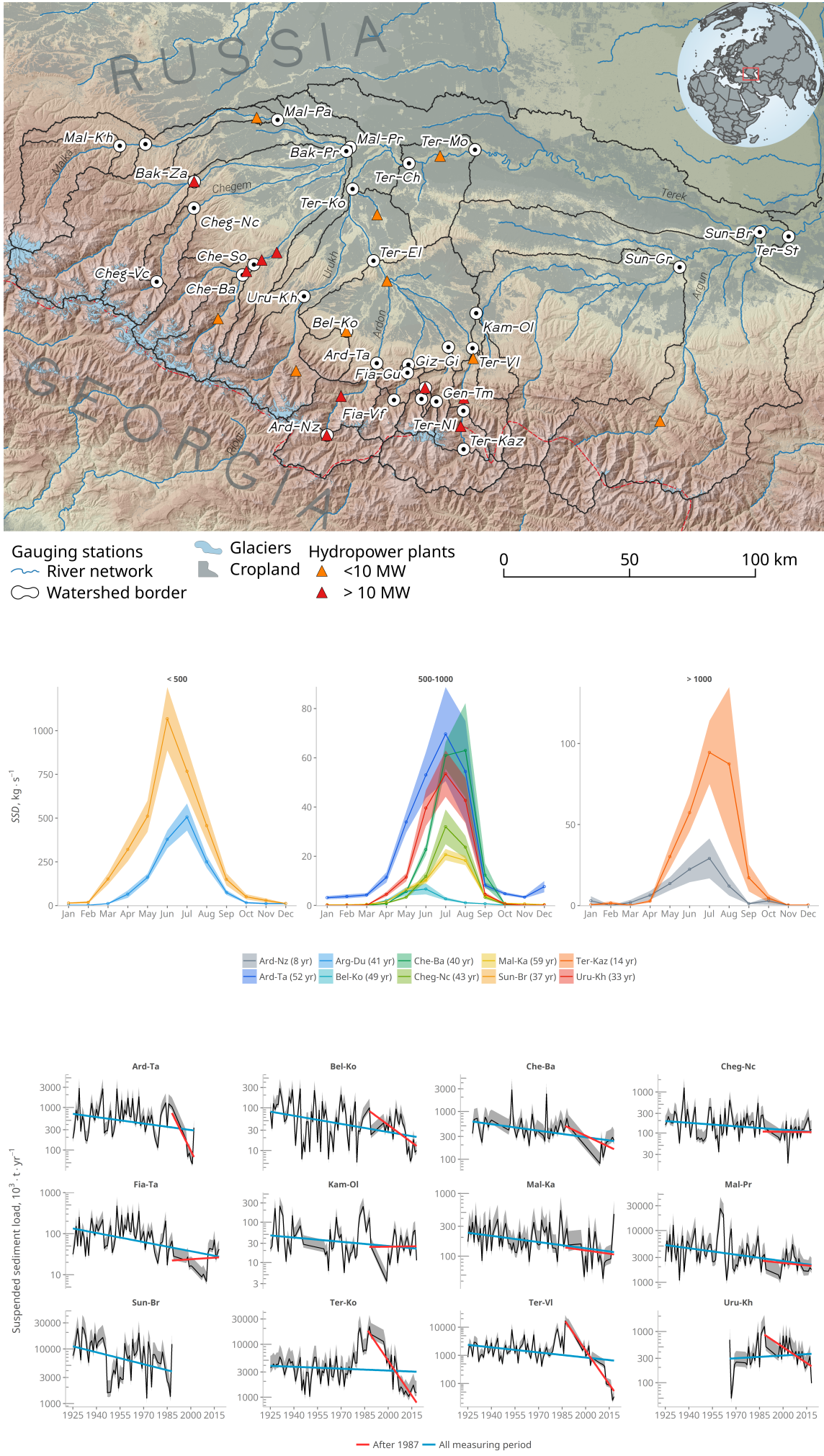

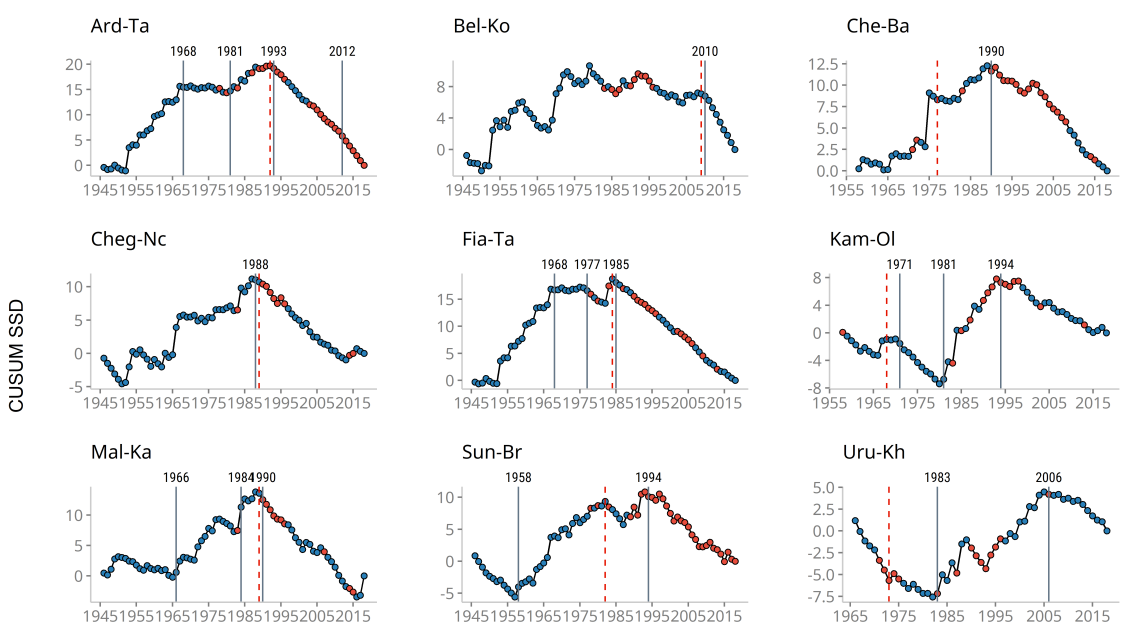

Changepoint test $\mid$ (Pettitt, 1979) $\mid$ (Taylor, 2000) Mean Annual SSD • Imputed • Observed
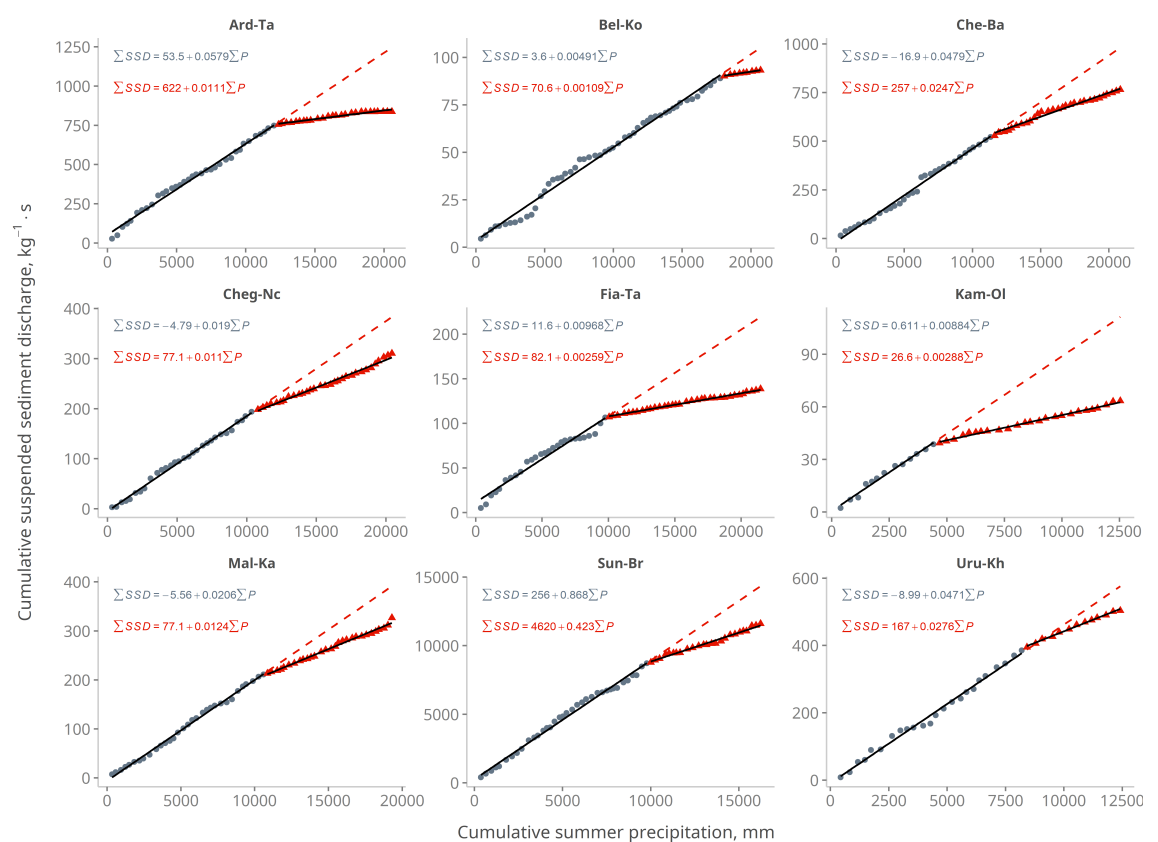

Transition year: - - - before $\mathbf{A -}$ - after 


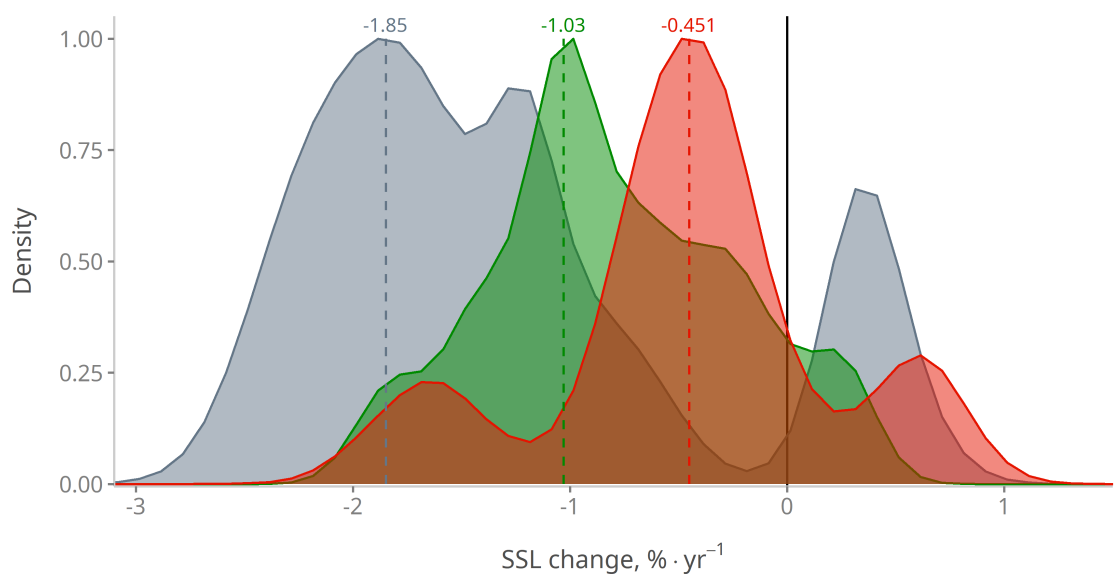

Altitude group $\square<500 \square 500-1000 \square>1000$

(a)

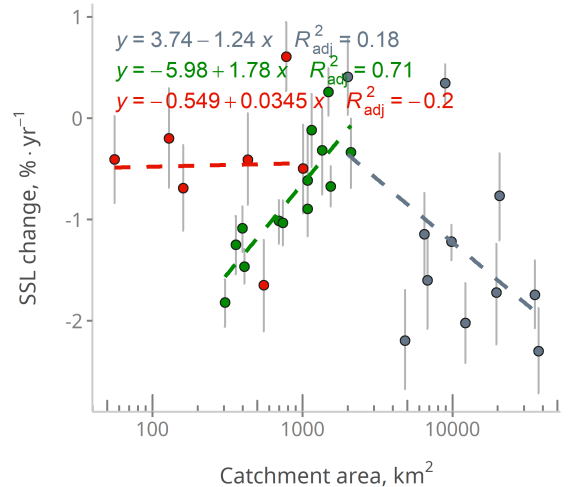

(c)

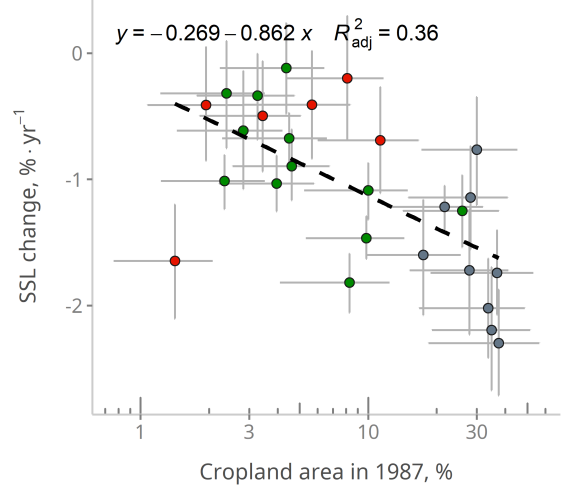

(b)

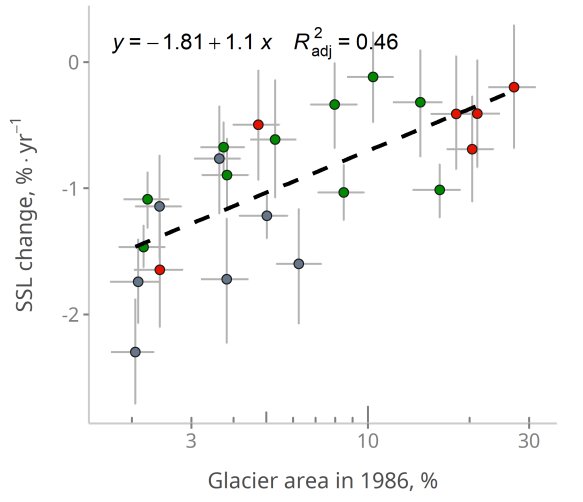

(d)

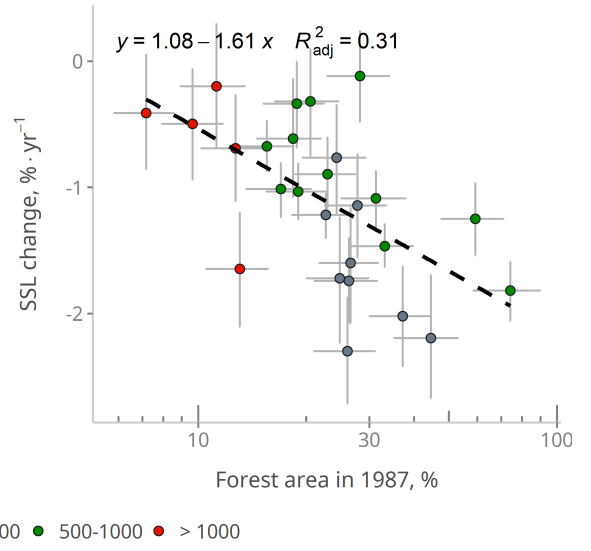




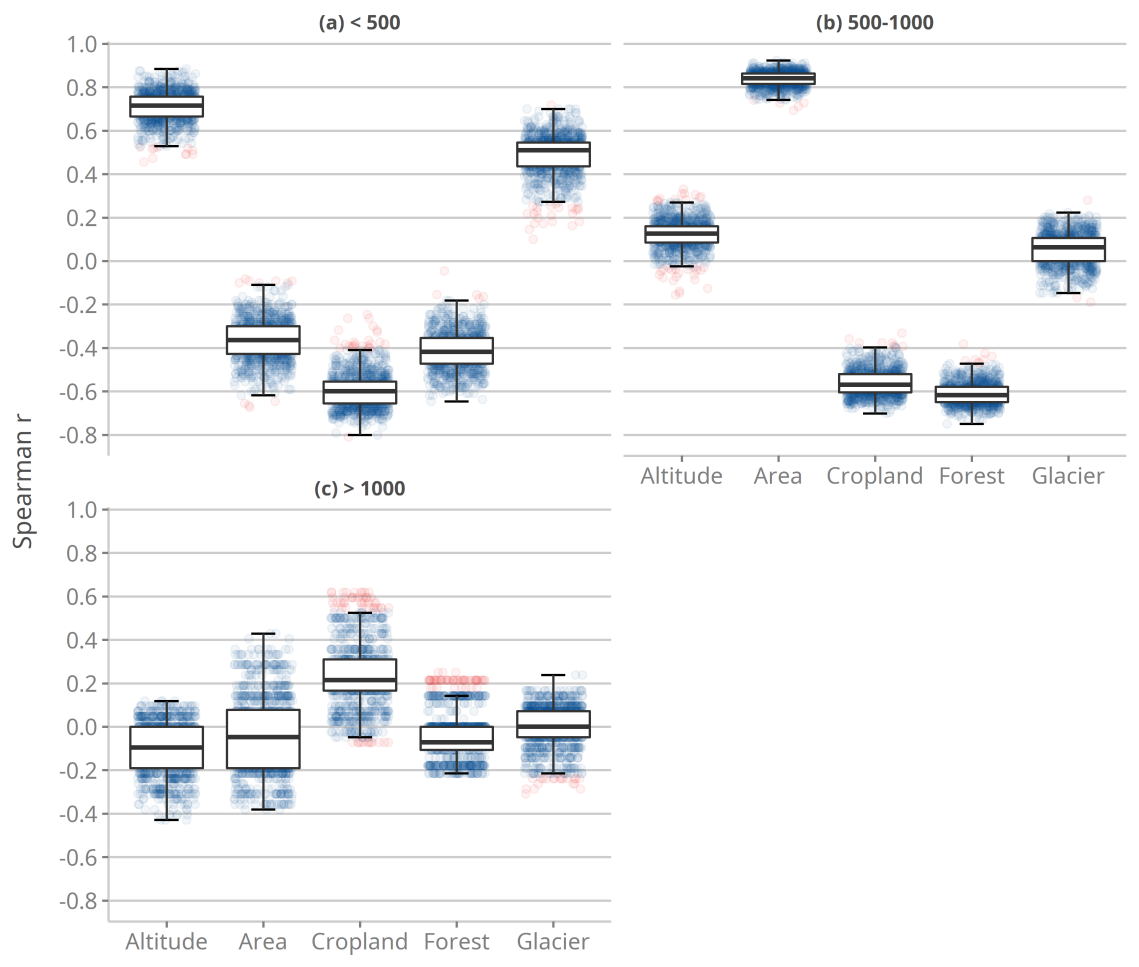

